\title{
Silicate-replacive high sulfidation massive sulfide orebodies in a porphyry Cu-Au system: Bor, Serbia
}

\author{
Dina Klimentyeva ${ }^{1}$ (D) $\cdot$ Thomas Driesner ${ }^{1} \cdot$ Albrecht von Quadt ${ }^{1} \cdot$ Trajča Tončić $^{2} \cdot$ Christoph Heinrich $^{1}$
}

Received: 15 April 2020 / Accepted: 20 October 2020 / Published online: 11 December 2020

(C) The Author(s) 2020

\begin{abstract}
The $\mathrm{Cu}$-Au deposit of Bor (Serbia) represents a continuum of mineralization styles, from porphyry-style ore occurring in quartzmagnetite-chalcopyrite veins and chalcopyrite disseminations to high-sulfidation epithermal $\mathrm{Cu}$ - $\mathrm{Au}$ ores in pyrite-chalcopyrite and anhydrite-sulfide veins. Decisive for the great economic importance of Bor is the presence of exceptionally rich highsulfidation massive sulfide orebodies, composed of pyrite + covellite + chalcocite/digenite and minor anhydrite and enargite. They form irregular bodies measuring $0.5-10$ million tons of ore grading up to $7 \% \mathrm{Cu}$, hosted by andesites and surrounded by intense argillic alteration. This study focuses on a small but rich underground orebody mined out recently, where limited drillcore is preserved for quantitative geochemical study. This paper documents the vein relationships within the deep porphyry-style orebody of Borska Reka, the transitional porphyry-epithermal veins, and the overlying and laterally surrounding epithermal massive sulfides of the Bor deposit. Geological observations indicate that the formation of massive sulfide orebodies concludes the ore formation. Mass balance calculations, recast into geologically realistic bulk fluid-rock reactions, confirm textural evidence that near-isovolumetric replacement of andesite host rocks is the dominant formation mechanism of massive sulfide orebodies at Bor, whereby all lithophile elements including $\mathrm{Si}$ are dissolved and only Ti stays relatively immobile. While net volume changes for individual mineralization styles within the massive sulfide orebody vary from $-16 \%$ volume loss to $+127 \%$ volume gain, overall volume change for the whole massive sulfide orebody was probably slightly negative. Brecciation is important only as means of creating channelways for reactive fluid that turns the andesite protolith into massive sulfide, whereas net breccia infill occurred only locally.
\end{abstract}

Keywords Porphyry $\mathrm{Cu}-\mathrm{Au} \cdot$ Massive sulfide $\cdot$ Mass balance

\section{Introduction}

Porphyry Cu-Au systems (Hedenquist and Lowenstern 1994; Sillitoe 2010) are magmatic-hydrothermal ore systems that commonly include two spatially associated and genetically linked styles of $\mathrm{Cu}-\mathrm{Au}$ ore. Porphyry-style mineralization

Editorial handling: B. Lehmann

Supplementary Information The online version contains supplementary material available at https://doi.org/10.1007/s00126-02001023-2.

Dina Klimentyeva

Dina.klimentyeva@erdw.ethz.ch

1 Institute of Geochemistry and Petrology, ETH Zürich, 8092 Zürich, Switzerland

2 Zijin Bor Copper D.O.O., Bor 19210, Serbia holds the bulk of the economic ore in large-tonnage but relatively low-grade orebodies dominated by chalcopyrite \pm bornite in and around stockwork veinlets. Epithermal mineralization typically overlies or is adjacent to the porphyry ores and postdates them and mostly occurs in swarms of discrete veins or more diffuse fracture zones containing pyrite with highsulfidation $\mathrm{Fe}-\mathrm{Cu}-\mathrm{As}-\mathrm{Au}-\mathrm{S}$ assemblages. Examples of this association include Butte, Montana (Meyer et al. 1968; Rusk et al. 2008), Far Southeast-Lepanto in the Philippines (Mancano and Campbell 1995; Arribas et al. 1995b; Hedenquist et al. 1998), La Famatina in Argentina (LosadaCalderón and McPhail 1996; Pudack et al. 2009), Elatsite Chelopech in Bulgaria (Chambefort and Moritz 2014), Oyu Tolgoi in Mongolia (Crane et al. 2012), and Valeriano in Chile (Sillitoe et al. 2016). The high-sulfidation assemblages comprise abundant pyrite with enargite + covellite \pm digenite \pm native sulfur. These are typically associated with advanced argillic alteration with residual quartz + alunite \pm kaolinite \pm 
anhydrite, giving rise to the alternative definition of the deposits as kaolinite-alunite-type epithermal deposits (Heald et al. 1987; Berger and Henley 1989). Silica-rich alteration (commonly named "vuggy quartz") is typically generated in an early stage of the paragenetic evolution, probably by magmatic vapor in a sub-fumarolic environment (Stoffregen 1987; Arribas et al. 1995a; Heinrich et al. 2004). By contrast, later sulfide mineralization into vuggy quartz is dominated by lowsalinity aqueous fluids (Mancano and Campbell 1995; Arribas et al. 1995a, b) that may have a deeper magmatic origin followed by cooling and contraction of a single-phase intermediate-density fluid (Arribas 1995; Hedenquist et al. 1998) or magmatic vapor that had condensed some brine in the porphyry environment at depth (Henley and McNabb 1978; Heinrich 2005). Thereby the low-salinity magmatic fluid becomes miscible with meteoric water (Sillitoe 1983) or seawater (Gruen et al. 2014) but also allows re-mixing with entrained magmatic brine (Hedenquist et al. 1994; Wang et al. 1999). An entirely different idea calls on direct condensation of an As-rich sulfide melt from high-temperature magmatic gas (Mavrogenes et al. 2010).

Many high-sulfidation $\mathrm{Cu}-\mathrm{Au}$ ores are silica-rich and, due to their environmentally detrimental content of enargite and other As or Sb-rich sulfosalts, are rarely mined for $\mathrm{Cu}$ and mainly gain major economic significance as easily leachable $\mathrm{Au}$ deposits after pervasive supergene oxidation, e.g., Yanacocha (Longo et al. 2010), Pierina (Rainbow 2009), and Zijinshan (Chen et al. 2019; Pan et al. 2019). However, a few porphyry systems contain massive high-sulfidation orebodies that are of such high copper grade that they became world-class base metal deposits in their own right and were historically mined even before the lower-grade porphyry ores became exploitable. The most important example is Butte (Montana) where a swarm of major open fractures was filled by high-sulfidation sulfide minerals forming the Main Stage Veins (Weed 1912; Meyer et al. 1968). At Cerro de Pasco, polymetallic $\mathrm{Zn}-\mathrm{Pb}-\mathrm{Cu}$ ores with massive pyrite are formed at the contact between a diatreme and the adjacent limestone by carbonate replacement, which caused the neutralization of low-pH fluids (Baumgartner et al. 2008; Rottier et al. 2016). More enigmatic deposits are dominated by massive sulfide orebodies of irregular, tabular, or pipe-like shape lacking obvious evidence of open space creation or reaction with readily dissolvable carbonate host rocks. These include Lepanto in the Philippines, Frieda River in Papua New Guinea, Recsk in Hungary, Chelopech and Radka in Bulgaria, and Bor in Serbia (Sillitoe 1983; Popov 2001; Chambefort and Moritz 2014). Bor had great historic importance as one of the largest and highest-grade copper deposits of Europe (Lazarević 1909; Mempel 1937; Schumacher 1954; Janković et al. 1980; Janković 1990; Janković et al. 2002; Koželj 2002; Jelenković et al. 2016; Knaak et al. 2016). The deposit is of renewed interest thanks to the recent discovery of a similar high-grade orebody at Cukaru Peki (Banješević et al. 2014; Jelenković et al. 2016; Koželj et al. 2016; Jakubec et al. 2018). The origin of these massive sulfide deposits has been debated, initially being interpreted as submarine-exhalative volcanichosted massive sulfide deposits due to their association with partly submarine volcanics and locally layered pyrite textures (Drovenik 1953; Drovenik et al. 1975; Bogdanov 1984). Today, they are accepted to be variants of high-sulfidation epithermal deposits due to their clearly epigenetic nature and their association with porphyry ore systems (Sillitoe 1980; Kouzmanov et al. 2009; Chambefort and Moritz 2014). However, the nature and origin of these sharply bounded orebodies, typically measuring tens of meters in all directions and $\mathrm{Cu}$ grades reaching $10 \%$, remain poorly described and understood despite their economic attractiveness. Although brecciation and open-space filling are observed locally (Chambefort 2005), we show here that one of the largest and richest deposits of this type is formed by largely texturepreserving replacement of volcanic rocks, as suggested already by Sillitoe (1980).

The copper-gold deposit of Bor in Serbia has recently become partly accessible to research in the course of renewed exploration, based on a cooperation between international investors and the Serbian State as main owner (Jamasmie 2018). This paper is a new geological description of related ore types in the deposit, which includes a deep porphyry-style vein stockwork, as the largest remaining resource, and partly preserved higher levels accessible in exploration adits, including a recently mined massive sulfide orebody. The main focus of the paper is to combine textural evidence with mass balance data based on bulk rock analyses, to test whether the massive sulfide orebodies indeed formed by nearly isovolumetric replacement of volcanic rocks. These results will later be used to model possible fluid evolution paths that could generate such unusual, easily missed but high-value orebodies.

\section{Geological background}

The Apuseni-Banat-Timok-Srednogorie belt (ABTS, Fig. 1 inset) is a magmatic arc that was active during the Late Cretaceous (92-67 Ma) and formed due to the subduction of the Vardar Ocean (part of the Neo-Tethys) beneath the complex southern continental margin of the Eurasian plate. This Andean-type arc was preceded by earlier nappe emplacement and later overprinted by the effects of continental collision with the Adriatic microplate during Tertiary times (Kolb et al. 2012; Gallhofer et al. 2015). In the period from 92 to $67 \mathrm{Ma}$, arc magmatism became younger away from the European continental margin, towards the west in Serbia and towards the south in Bulgaria (Gallhofer et al. 2015), which is interpreted to reflect progressive roll-back of the subducted slab (Von Quadt et al. 2002; Von Quadt et al. 2005; Kolb 


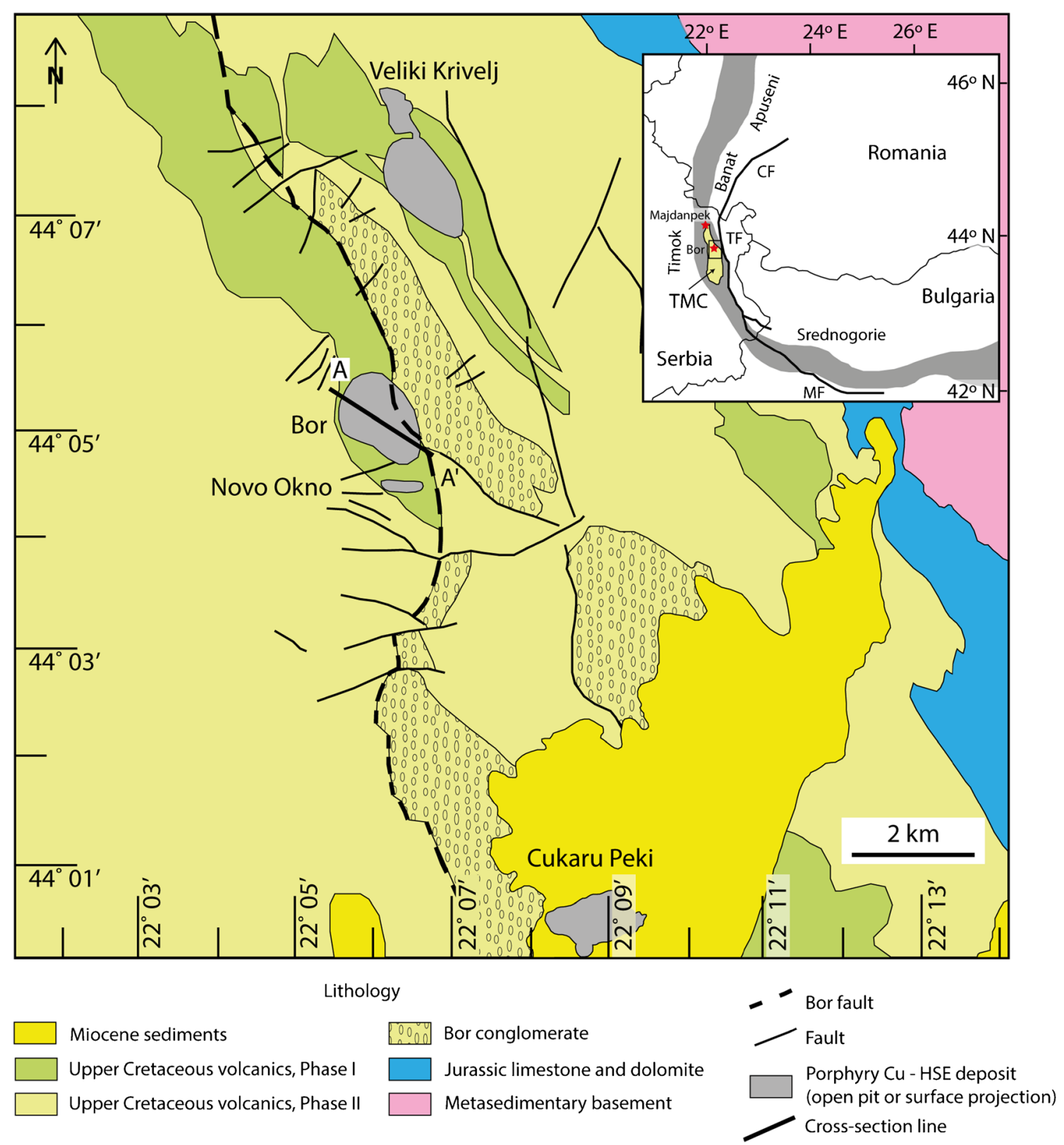

Fig. 1 Southeastern area of the Timok Magmatic Complex and the location of the Timok Magmatic Complex within the Apuseni-BanatTimok-Srednogorie belt (inset). Modified after Mioč (1983), Đorđević and Banješević (1997), Knaak et al. (2016), and Pittuck and McGurk

et al. 2012). After its emplacement, the arc was bent around the European foreland as a result of syn- to post-collisional deformation (Schmid et al. 2008; Knaak et al. 2016), including more than $100 \mathrm{~km}$ of accumulated dextral movement along the Timok-Cerna fault system (CF - TF in Fig. 1, inset; Matenco and Radivojević 2012). Regional geology and geochronology of the Bor metallogenic zone and the Timok magmatic complex (TMC), the largest area of preserved volcanic rocks in the ABTS belt (Fig. 1), have been summarized by Antula (1909), Schumacher (1954), Janković (1977), Von Quadt et al. (2002), Banješević (2010), Gallhofer et al.
(2016). CF, Cerna fault system; TF, Timok fault system; MF, Maritsa fault system. Line A - A' marks the position of the deposit section in Fig. 2

(2015), Jelenković et al. (2016), and Knaak et al. (2016). Neoproterozoic and Paleozoic metamorphic rocks constitute the basement of the TMC, which is deformed and overlain by Jurassic to Early Cretaceous limestones and sandstones. Albian glauconitic sandstone rests unconformably on Aptian limestones, overlain by the volcanic rocks that range in composition from basaltic andesites to andesites (Banješević 2010).

The volcanic activity that formed the TMC took place during the Turonian stage of the Late Cretaceous epoch, with an estimated onset around $87 \mathrm{Ma}$ (Kolb 2011; Gallhofer et al. 
2015). It is sub-divided into three phases, two of which are significant for the Bor deposit geology (Fig. 1). Phase I, which hosts the deposits of Bor and Veliki Krivelj, is represented by conspicuously porphyritic-textured high potassium andesites, dominantly as lava flows but also as lava domes and some pyroclastic breccias, exposed mainly in the eastern part of the TMC. Euhedral amphibole phenocrysts are prominent and commonly reach a centimeter in size; zoned plagioclase with 40-50\% anorthite component (Janković et al. 2002) is similar to amphibole in terms of abundance at about $25-35 \%$, while biotite, magnetite, and quartz are subordinate. Occasional pyroxene represents a minor component of the phenocryst assemblage. The matrix contains fine-grained plagioclase, biotite, and quartz and amounts to $40-50 \%$ of the rock (Banješević 2010; Antonijević and Mijatović 2014).

Phase II, which comprises most of the area of the Timok complex, is represented by more matrix-rich (>50\%) pyroxene-phyric basaltic andesites, which locally show evidence of submarine extrusion (Banješević 2010). Augite clinopyroxene and plagioclase with 42-93\% anorthite content are prevalent among the phenocrysts and are generally smaller than the phenocrysts of the phase I andesite; enstatite and tschermakitic amphibole locally are subordinate phenocryst components (Banješević 2010). These rocks are of Santonian to Lower Campanian age based on fossil evidence from the interbedded marine sedimentary rocks (Banješević et al. 2006).

The concluding phase III of magmatic activity is manifested in latites that are outcropping in the southwestern part of the TMC, dominantly as small-scale dikes and subvolcanic intrusions, rarely as lava flows, and are composed of plagioclase and $\mathrm{K}$-feldspar phenocrysts set in a fine-grained to hypocrystalline matrix (Banješević 2010). The age of the latite is defined as Campanian to Lower Maastrichtian (Karamata et al. 1997).

The Bor metallogenic zone is located near the eastern margin of the TMC (Fig. 1) extending from Serbia into Romania (Grubić 1974; Janković 1977) and contains the porphyry copper deposits of Majdanpek and Veliki Krivelj, the porphyryhigh-sulfidation epithermal deposits of Bor and recently discovered Cukaru Peki (Antula 1909; Schumacher 1954; Janković 1997; Karamata et al. 1997; Berza et al. 1998; Jelenković et al. 2016). Total $\mathrm{Cu}$ endowment of the Bor metallogenic zone is estimated at 20 million metric tons (Mt) of $\mathrm{Cu}$ and $1000 \mathrm{t}$ of $\mathrm{Au}$ (Jelenković et al. 2016); measured and indicated resources of the Bor deposit (dominated by Borska Reka and Tilva Ros) amount to $5.8 \mathrm{Mt} \mathrm{Cu}$ at a grade of $0.3 \%$ and $260 \mathrm{t} \mathrm{Au}$ (Tončić 2018), while the total endowment of Bor group of deposits is estimated at $6.72 \mathrm{Mt}$ and a grade of $0.84 \%$ (Baker 2019).

The Bor deposit is hosted by hornblende andesite and pyroxene-hornblende andesite; these are referred to as phase I and phase II andesites, respectively (Đorđević and
Banješević 1997; Đorđević 2005; Banješević 2010). The deposit is truncated at the base and eastern side by the Bor fault and underlying Bor conglomerate, a former late- to postdepositional graben structure that was subsequently reactivated by overthrusting of the package of mineralized volcanic rocks towards the east (Janković et al. 2002; Đorđević 2005). All deposits of the Bor metallogenic zone (Fig. 1), including the Veliki Krivelj porphyry and the new Cukaru Peki, are hosted by andesites of phase I and are overlain by epiclastic layers of andesitic and dacitic composition of phase II that are intercalated with pelites (Fig. 2; Koželj 2002; Jelenković et al. 2016).

Age and duration of mineralization at Bor are poorly constrained between $\sim 84.5$ and $\sim 82 \mathrm{Ma}$ (Fig. 3). Ages of phase I andesites in the vicinity of Veliki Krivelj were established by ID-TIMS of zircons at $86.29 \pm 0.32 \mathrm{Ma}$ and $84.17 \pm 0.86 \mathrm{Ma}$, overlapping with an approximate LAICPMS age of $84.28 \pm 0.86 \mathrm{Ma}$ for a sample of dacite in close proximity to the Bor mine (Kolb 2011). A trachyte dike that cuts phase II andesites $5 \mathrm{~km}$ south of Bor yielded an ID-TIMS age of $82.35 \pm 0.35 \mathrm{Ma}$ as the only well-dated post-mineral intrusion (Kolb 2011). ${ }^{40} \mathrm{Ar}-{ }^{39} \mathrm{Ar}$ plateau ages of igneous hornblende from phase I andesite in the vicinity of Bor are reported as $83.4 \pm 1.7 \mathrm{Ma}$ and $84.6 \pm 1.1 \mathrm{Ma}$ (Lips et al. 2004). Alteration minerals at Bor were dated by ${ }^{40} \mathrm{Ar}-{ }^{39} \mathrm{Ar}$ and $\mathrm{K}-\mathrm{Ar}$ methods and overlap within the analytical uncertainty with the magmatic ages of the dacite, with $84.8 \pm 1.9 \mathrm{Ma}, 86.9 \pm$ 1.1 Ma and $85.9 \pm 1.7 \mathrm{Ma}$ for white mica from the Borska Reka porphyry ore and $84.6 \pm 1.2 \mathrm{Ma}$ for alunite from the advanced argillic alteration zone in the Bor mine (Lips et al. 2004; Lerouge et al. 2005). Re-Os dating of molybdenite from Bor yielded significantly older ages of $86.24 \pm 0.5 \mathrm{Ma}$ and $85.94 \pm 0.4 \mathrm{Ma}$ (Zimmerman et al. 2008), similar to the older ID-TIMS age at Veliki Krivelj. Magmatic and hydrothermal activity at Bor probably occurred around $84-85 \mathrm{Ma}$ and was related to late Phase I magmatism, as indicated by ${ }^{40} \mathrm{Ar}-{ }^{39} \mathrm{Ar}$ and K-Ar ages of alunite and white mica and ${ }^{40} \mathrm{Ar}-{ }^{39} \mathrm{Ar}$ age of hornblende of phase I andesite from the Bor mine and U-Pb zircon age of the dacite in the vicinity of Bor mine. We suspect that Re-Os ages of molybdenite are probably overestimated.

The orebodies at Bor are hosted entirely by phase I andesites (Figs. 1 and 2). The least-altered andesites from the periphery of Borska Reka display the typical porphyritic texture defined by euhedral amphibole, plagioclase, and subhedral biotite phenocrysts, partially altered to chlorite and sericite with minor pyrite and chalcopyrite.

Diorite porphyry dikes, 50-150 m wide, were logged at the deep levels of Borska Reka (Janković et al. 1980), but their true dip direction is uncertain because no core is preserved. Shallower, small-scale porphyry dikes are present in the central part of Borska Reka (T. Toncić, pers. commun.), and a single $1.5-\mathrm{m}$ core interval was tentatively logged as a diorite 


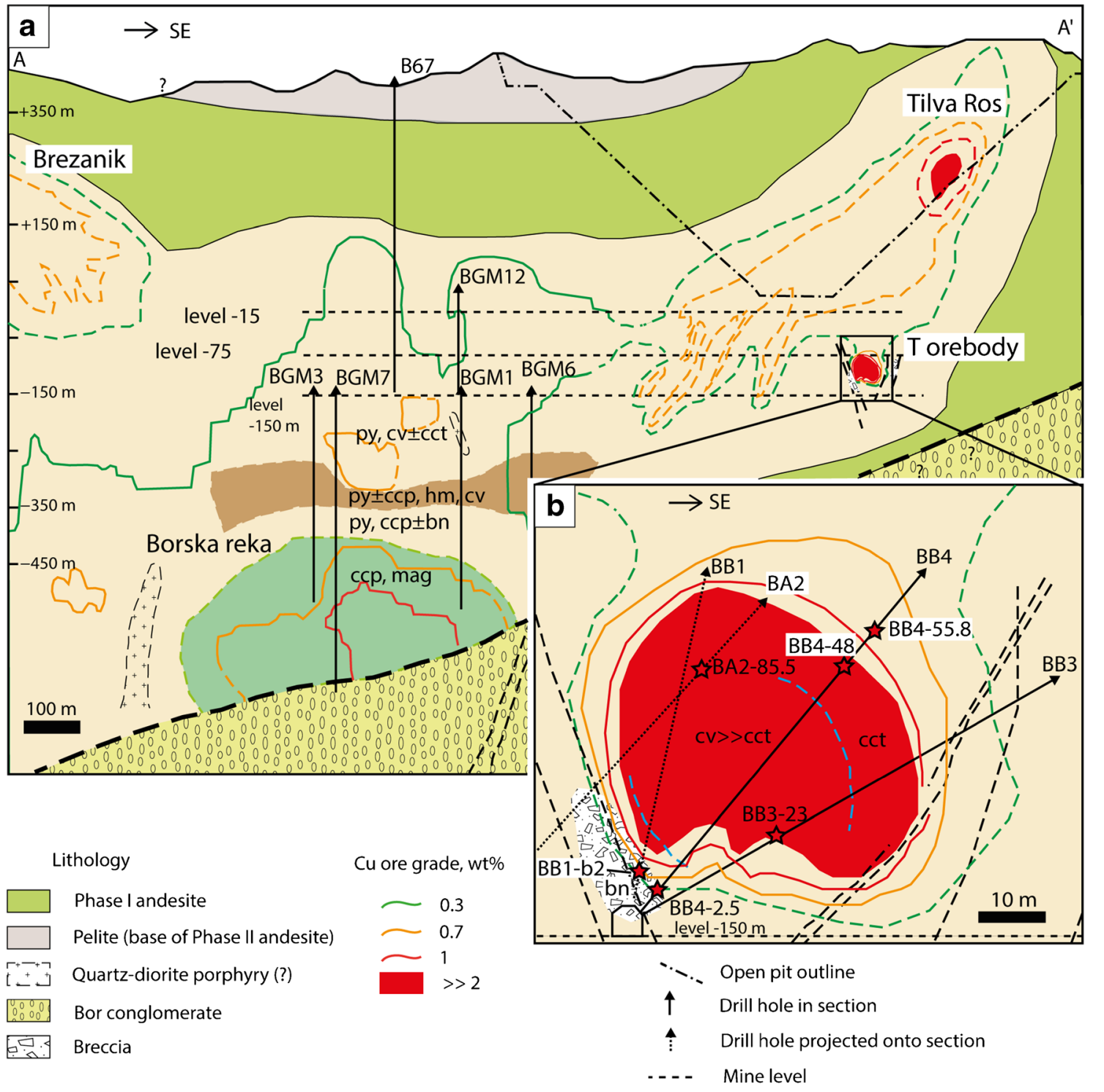

Approximate distribution of alteration and ore minerals

BB1 Drill hole ID

Quartz - kaolinite - anhydrite - diaspore,

pyrite - chalcopyrite - bornite in the lower part, covellite \pm chalcocite in the upper part of the section

Quartz - sericite - pyrite - hematite \pm covellite, occasional chalcopyrite

BB3-23 Sample number (drill hole ID + depth)

- Bor fault

\ Sample location

Chlorite - sericite - magnetite, pyrite with pyrrhotite inclusions, chalcopyrite, occasional hematite

Fig. 2 Cross-section through the Bor deposit, showing the apparent continuum between porphyry-style ores at Borska Reka and epithermal ore types, including the former Tilva Ros massive sulfide body in the open pit, combining personal observations and unpublished mine sections. a Colored grade contours delineate the projected mineralization based on current assay data for the Borska Reka porphyry (solid lines), and approximate position of mineralization and alteration zones for Tilva Ros and Brezanik orebodies based on historic assay data and interpolation (dashed). Position, thickness, and orientation of porphyry dikes are uncertain projections from mine data. Alteration types within the phase I

dike during our field campaign. Largely texture-destructive alteration precludes reliable mapping of intrusive contacts, andesites are confirmed in the central region by partly preserved drillcore (vertical lines) and near T orebody, or interpolated and projected from other mine sections elsewhere. b Cross-section through $\mathrm{T}$ massive sulfide orebody, showing the zonation of the mineral assemblages, from bornite + chalcopyrite + pyrite in the bottom part of the orebody to predominantly covellite with pyrite in the central part, and chalcocite + pyrite in the rim. Abbreviations: bn, bornite; ccp, chalcopyrite; cct, chalcocite; cv, covellite; hm, hematite; mag, magnetite; py, pyrite. After Starostin (1970), Janković et al. (2002), and Jelenković et al. (2016), with additions based on Bor mine geologic documentation

but an indication of crowded equigranular texture and the larger abundance of zircons compared to immediately 
Magmatic activity

Bor and its surroundings

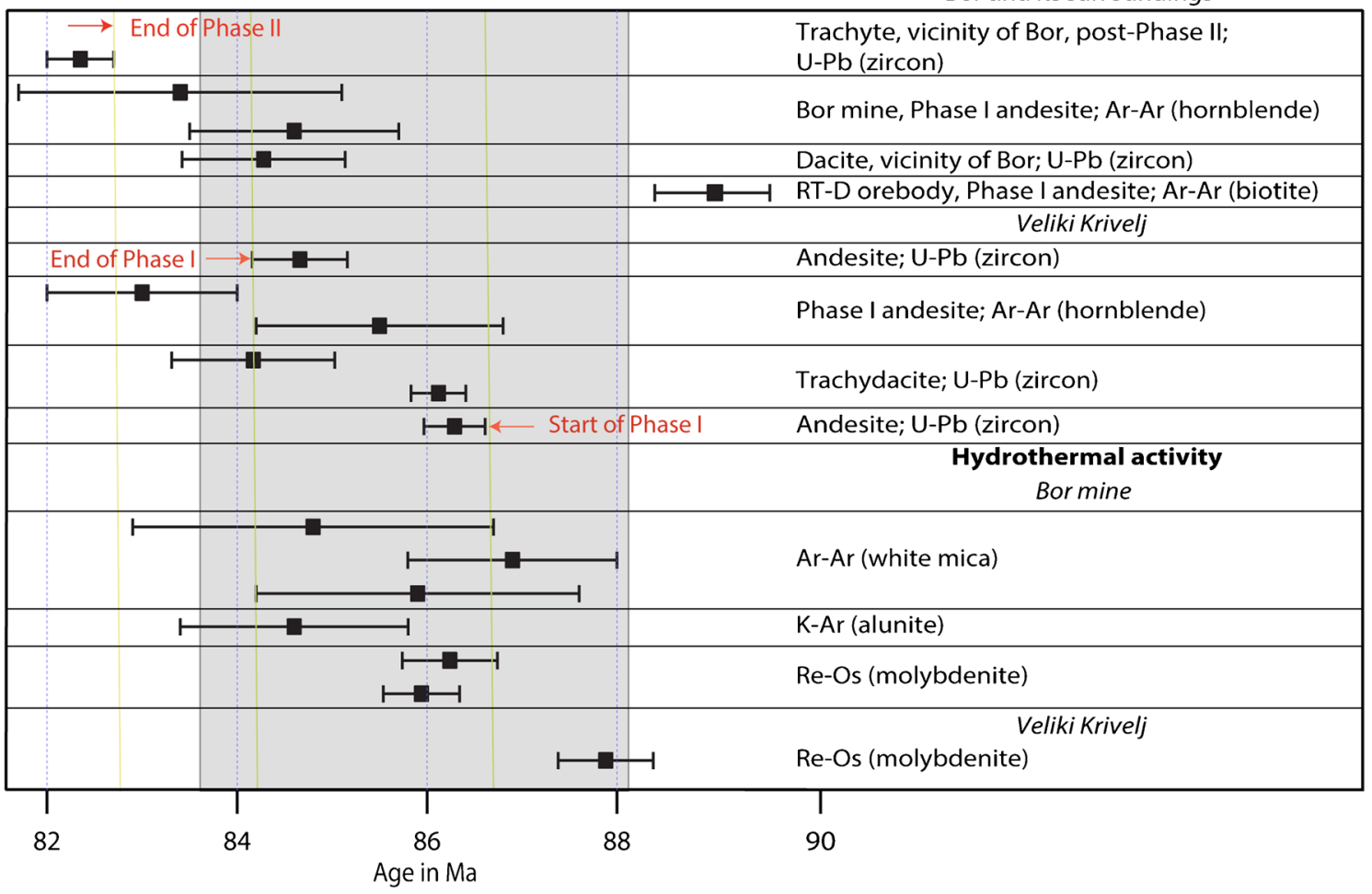

Fig. 3 Geochronology of the Bor deposit, with likely age brackets encompassing all ore types indicated by the gray bar (Lips et al. 2004; Lerouge et al. 2005; Von Quadt et al. 2007; Zimmerman et al. 2008; Kolb 2011)

neighboring andesite are evidence in favor of a subvolcanic intrusive origin (sample BGM1-64.8).

The Bor conglomerates (Fig. 4) outcrop to the east and to the south of Bor and are observed in the Bor mine as footwall unit below the Bor fault (Fig. 2). The Bor conglomerate contains rounded clasts of basement gneiss, andesite with kaolinite alteration, and limestone and marls of Campanian to Maastrichtian age $(\sim 72-66 \mathrm{Ma})$ based on planktonic
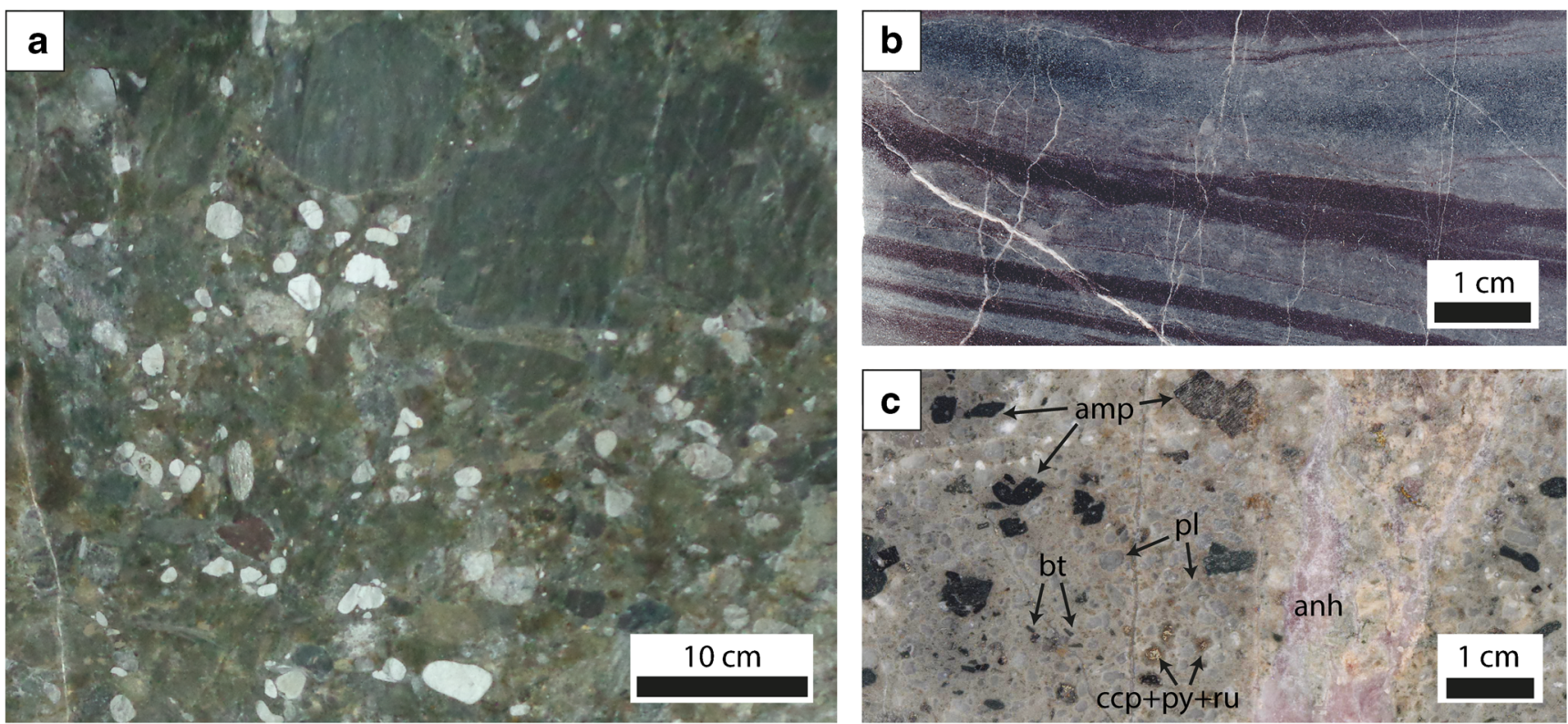

Fig. 4 Main lithologies at Bor. a Bor conglomerates from - 155 mine level. b Pelite, base of phase II andesite overlying phase I andesite, B6735.8. $\mathbf{c}$ Phase I andesite with weak chlorite-sericite alteration, anhydrite- gypsum vein; BGM12-86.3. Sample labels indicate drill hole numbers (i.e., BGM12) and depth (i.e., $86.3 \mathrm{~m}$ ). See Fig. 2 for the location of the drill holes 
foraminifera (Janković et al. 2002; Ljubović-Obradović et al. 2011). To the south of Bor, conglomerates made up of mineralized clasts constitute the deposit of Novo Okno, with clasts of covellite + pyrite in the lower part, chalcopyrite + bornite in the middle, and pyrite + chalcopyrite on top and at the periphery of the deposit (Antonijević 2011), representing an inverted sequence observed within the massive sulfide bodies at Bor and indicating exposure and erosion of the deposit by Late Cretaceous time. Outside the mine area, the conglomerates are overlain by Maastrichtian sandstone and claystone with Gansserina Gansseri, which defines their youngest age as Maastrichtian (Ljubović-Obradović et al. 2011), indicating exposure of the Bor deposit some 10-15 Ma after its formation.

\section{Geology of the Bor deposit}

A range of mineralization styles is present at Bor, varying from the deep porphyry-style stockwork orebody of Borska Reka to the shallow epithermal mineralization of the Tilva Ros orebody, the former center of a large open pit mine that was closed in 1993 and is inaccessible today (Fig. 2a). Most of the massive sulfide orebodies including Tilva Ros and the smaller L, T, T1, T2, and P2A massive sulfide bodies are located in the upper and southeastern margin of the deposit (Fig. 2; Janković et al. 2002; Koželj 2002). Remnants of the massive sulfide orebody T, high-sulfidation veins in the shallow Brezanik underground mine, and parts of the transition above Borska Reka are accessible in development tunnels, and together with minor preserved core from the deeper part of Borska Reka are the basis of this study. In the following sub-sections, four main styles of mineralization with characteristic vein types (Fig. 5) and macroscopic alteration and replacement relationships (Fig. 6) are described; microscopic evidence is presented in support of the suggested mineralization sequence (Fig. 7).

Weakly altered phase I andesites are intersected by shallow drill holes south at the level of the Tilva Ros epithermal orebody (Figs. 4c and 6a) and are characterized by partly preserved igneous amphibole, biotite, and relict magnetite (Fig. 7a). Plagioclase displays twinning and oscillatory zoning in the rim, with An-rich cores replaced by kaolinite, sericite, and anhydrite. Magnetite preserves the original grain shape, but shows dissolution pits, and in rare cases is partly replaced by hematite. The matrix contains unaltered plagioclase laths together with quartz, some fine-grained magnetite and chalcopyrite, and chlorite and accessory rutile. No evidence for stratigraphic orientation was observed within the massive andesites, but the overlying transitional shales to phase II andesites suggest subhorizontal disposition.

Porphyry-style stockwork ore with chlorite-sericite alteration is contained in magnetite-chalcopyrite-quartz veins and chalcopyrite disseminations in the deep part of Borska Reka, where alteration of the andesite is dominated by chlorite and sericite which probably overprinted potassic alteration in some places, as indicated by relictic magnetite although no hydrothermal biotite or K-feldspar is preserved (Figs. 5a and $7 b$ ). The upright cylindrical orebody is truncated by the barren Bor fault; the Bor conglomerates intersected by deep drill holes do not contain any amount of copper sulfides. In the upper parts of Borska Reka, barren quartz veins and ABtype quartz-chalcopyrite-pyrite \pm hematite veins, cross-cut by tiny pyrite \pm hematite stringers, become the main vein types, in wallrocks altered to quartz and sericite with variable overprint by anhydrite and kaolinite (Fig. 5b). In the chloritesericite alteration assemblage, most of the amphibole phenocrysts are replaced by chlorite, with significant amount of pyrite, sometimes with inclusions of co-entrapped pyrrhotite + chalcopyrite, chalcopyrite, and magnetite (Fig. 7b). Some relict quartz phenocrysts are preserved. Rutile precipitates along the former cleavage planes of amphibole and magnetite, and rims of rutile are formed around magnetite; the finegrained matrix consists of quartz and sericite. Magnetitechalcopyrite-quartz veins are composed of euhedral magnetite, altered at the rims to hematite, and anhedral chalcopyrite. Outer parts of pyrite overgrow and include both magnetite and chalcopyrite. Cores of the pyrite host inclusions of pyrrhotite intergrown with chalcopyrite, followed by chalcopyrite-only inclusions towards the rim. No intersection relationships were observed between magnetite-chalcopyrite veins and other vein types, but at shallower levels tiny magnetite veins cross-cut A-type quartz veins and are cross-cut by pyrite \pm chalcopyrite veins (Fig. 5c).

Chalcopyrite is present in tiny amounts as disseminations and as inclusions in pyrite, and in rare cases, chalcocite \pm covellite overgrows fractured pyrite together with hematite and anhydrite. The mineral name chalcocite is used in this paper as the overarching term for chalcocite group minerals including digenite. Where coexisting with covellite + pyrite in the ore matrix or late veins, chalcocite is usually gray with a greenish tint and somewhat higher reflectance than digenite in polished section; chalcocite predominates at Bor, except for small digenite inclusions in pyrite (commonly with bornite) which have the characteristic blue-gray color and reflectance. Quartz-sericite alteration is associated with somewhat lower $\mathrm{Cu}$ grade $(0.3-0.7 \mathrm{wt} \% \mathrm{Cu})$ than the best porphyry ore deeper in the section $(0.7-1 \mathrm{wt} \% \mathrm{Cu})$, with only minor chalcopyrite in the lower part and small anhydrite-chalcocite-hematite veinlets in the upper part of the interval, the latter presumably a weak expression of the shallow epithermal vein style resulting from re-opening of pyrite \pm hematite stringer veins. Very local monomictic clast-supported breccia is associated with the upper boundary of the quartz-sericite alteration zone, with clasts composed of quartz, pyrite with rare pyrrhotite inclusions, kaolinite, and rutile \pm hematite, set in the matrix comprising 

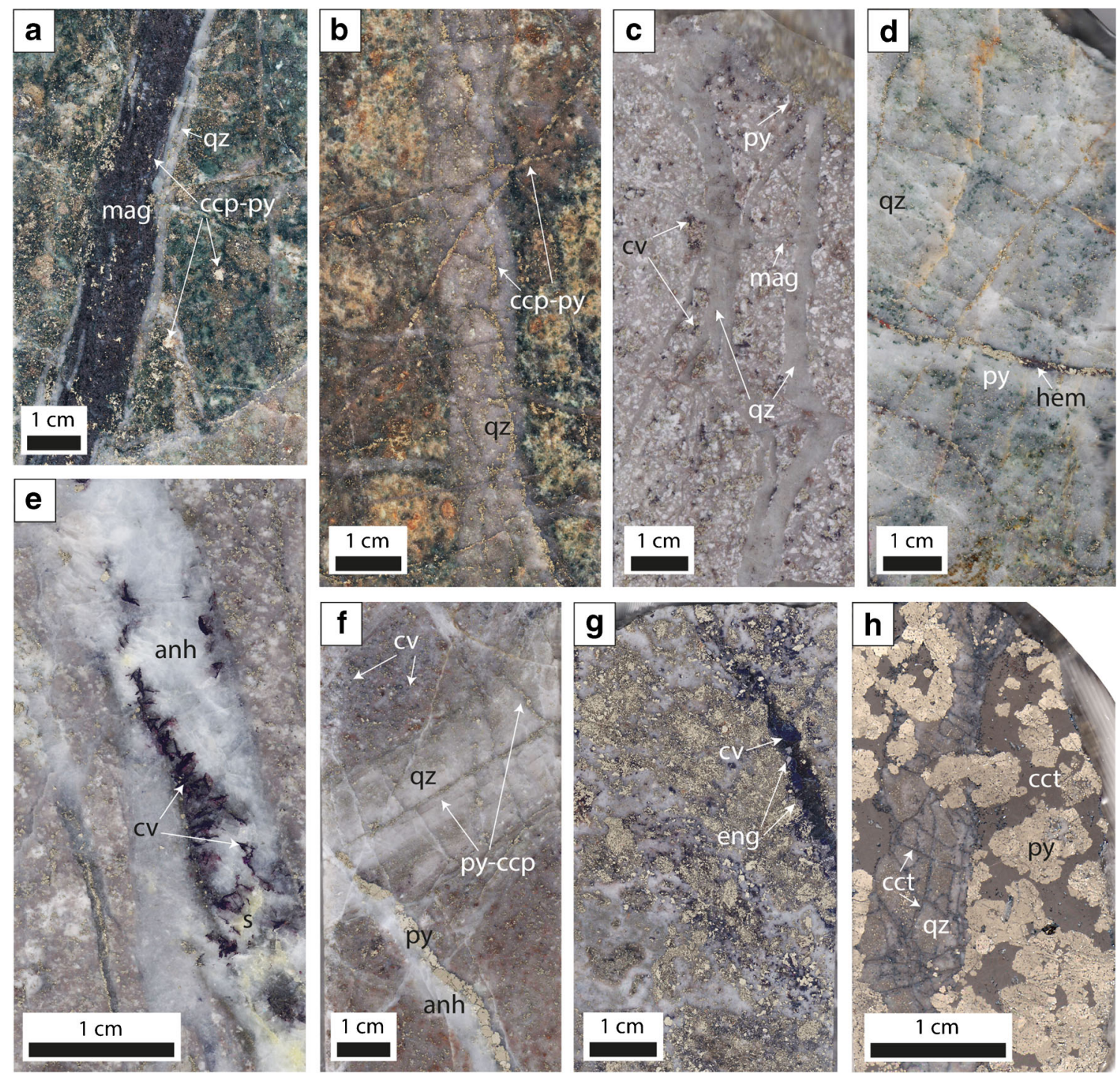

f Quartz AB-type vein with pyrite-chalcopyrite centerline cross-cut by pyrite-chalcopyrite veinlets and by a late anhydrite-pyrite vein, covellite disseminations; BGM1-6.5. g Quartz-covellite-enargite vein from the periphery of the $\mathrm{T}$ orebody in a matrix with disseminated pyrite, covellite and enargite; $\mathrm{BC} 18-40.1$. h High-grade massive sulfide ore from the central part of the T orebody: deformed quartz vein, A or AB-type with pyrite, chalcocite and minor anhydrite in the matrix of massive sulfide; BB4-48. Abbreviations: anh, anhydrite; ccp, chalcopyrite; cct, chalcocite; $\mathrm{cv}$, covellite; eng, enargite; hem, hematite; mag, magnetite; py, pyrite; qz, quartz; s, native sulfur quartz, anhydrite, pyrite, rutile \pm digenite, covellite, and colusite.

Low-grade high-sulfidation $\mathrm{Cu}$ ore with kaoliniteanhydrite alteration is transitional between the Borska Reka porphyry style and the Tilva Ros massive sulfides. This volumetrically dominant epithermal alteration in Fig. 2 corresponds to variably siliceous advanced argillic alteration including minor vuggy quartz. Compared with other epithermal deposits, it stands out due to the high abundance of anhydrite and only local occurrence minor alunite. It is characterized by $0.5-1-\mathrm{cm}$-thick veins with pyrite \pm chalcopyrite, and 1-2-cmthick anhydrite-sulfide veins with pyrite, covellite, enargite, and chalcocite, in wallrock alteration of kaolinite, anhydrite, and diaspore at the upper levels of the deposit (Figs. 5e and 7), with relict patches of chlorite-sericite alteration at the periphery. Both pyrite-chalcopyrite and anhydrite-sulfide veins cross-cut quartz A-type veins and quartz-pyrite AB-type veins. Thickness and abundance of anhydrite-sulfide veins 

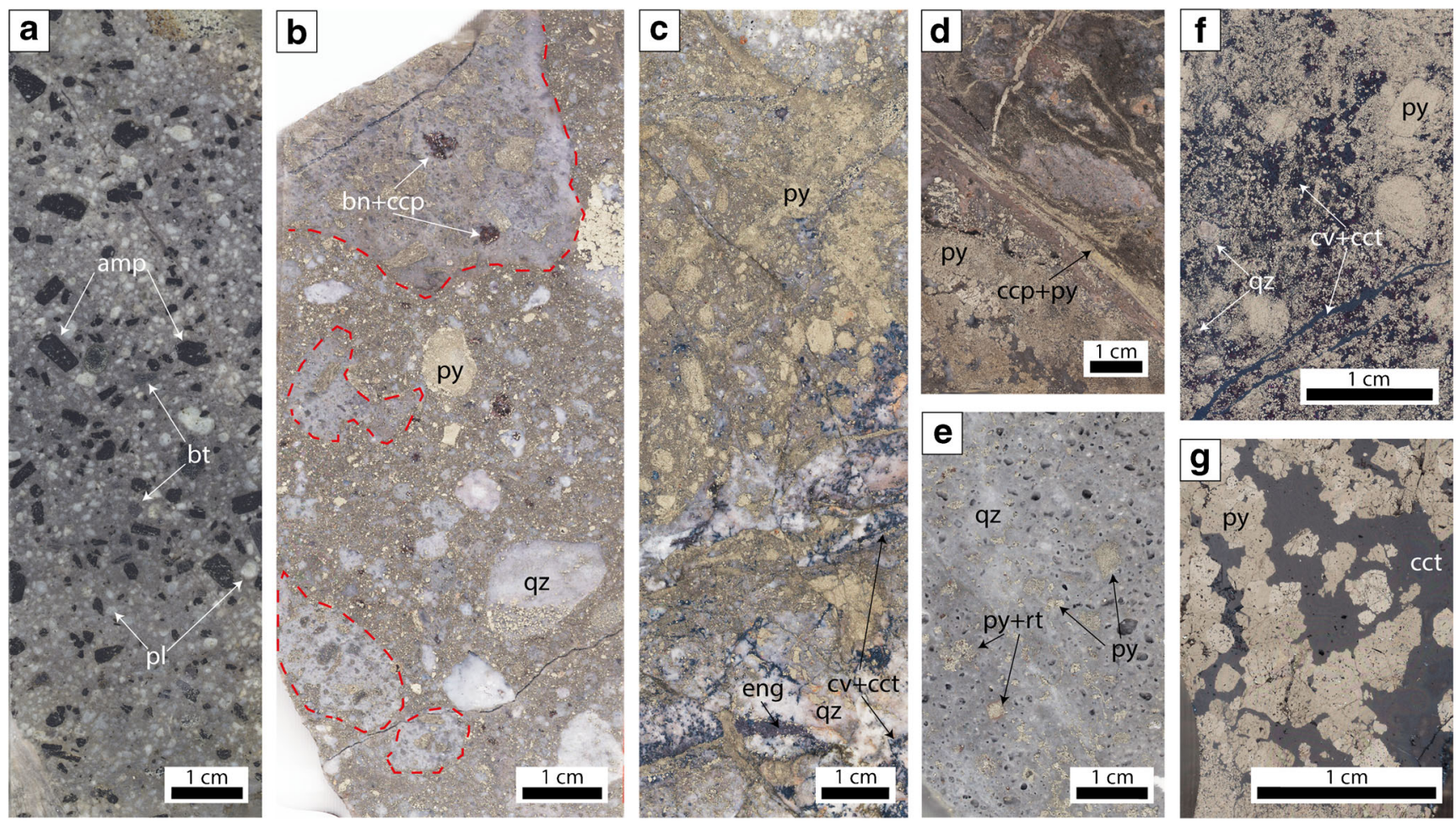

Fig. 6 Replacive textures advancing from andesite protolith to massive sulfide in and around $\mathrm{T}$ orebody, in representative samples described in the Digital Appendix A and used for geochemical mass balance analysis; for location of the drill hole see Fig. 2b. a Weakly altered phase I andesite protolith with euhedral amphibole and plagioclase phenocrysts; B67-258. b Monomictic breccia at the base of T orebody, with two types of clasts cemented by pyrite-rich matrix: partly sulfidized andesite clasts (red lines) with phyllic-argillic alteration and hydrothermal vein clasts of earlier hydrothermal quartz-sulfide AB-type veins; BB4-2.5. c Silicified advanced argillic breccia with relict former amphibole phenocrysts replaced

increase upwards; in the upper tunnels just below Tilva Ros, a 20 -cm-thick anhydrite-pyrite-covellite vein was observed. Generally, anhydrite-sulfide veins cross-cut pyrite \pm chalcopyrite veins (Fig. 5f), but the reverse cross-cutting relationships can occasionally be found, white anhydrite is the most important constituent in the veins and is prominent as an alteration mineral in this interval. Pyrite within anhydritesulfide veins is fractured and overgrown by spectacular blades of covellite, anhydrite, and chalcocite as well as minor enargite. Etching of the pyrite from high-sulfidation epithermal veins revealed at least two generations of pyrite (Fig. 8d). Apart from anhydrite-sulfide veins, copper is disseminated as covellite and as chalcopyrite inclusions in pyrite. Native sulfur was found in two samples, in the central part of anhydrite-sulfide veins (Fig. 5e). In contrast to the wellpreserved phenocryst shapes in the chlorite-sericite alteration assemblage, former grain boundaries of the phenocrysts are barely discernible within the kaolinite-anhydrite alteration domain (Fig. 5e, f).

High-grade massive sulfide ores exemplified by the $\mathrm{T}$ orebody (Fig. 2b) are distinguished by the highest ore grade, by pyrite; BB1-b2. d Advanced argillic alteration, pyrite and chalcopyrite veins; BA2-85.5. e Vuggy residual quartz with pyrite and kaolinite in the vugs, minor rutile; BB4-55.8. f High-grade massive sulfide ore with quartz from the central part of the orebody: pyrite showing relict shapes of replaced amphibole phenocrysts in a matrix of covellite, chalcocite, minor enargite, and residual quartz, with a late covellite veinlet crosscutting pyrite aggregates; BB3-23. g Completely recrystallized massive sulfide ore with euhedral pyrite grains and aggregates with inclusions of chalcocite and digenite, growing in a matrix of chalcocite and covellite; BB4-48

with $50-90 \%$ of the host rock replaced by sulfide minerals, namely pyrite, covellite, chalcocite, and enargite in decreasing abundance (Fig. 6). The massive sulfide T orebody has an equidimensional round shape with a diameter of $\sim 50 \mathrm{~m}$, is not delineated by any conspicuous extensional structures, and shows no major breccia infill textures, but seems to be formed by wholesale hydrothermal replacement of the host andesite. A detailed description of the representative sample suite from this orebody and its vicinity is presented in Digital Appendix A. Background alteration outside of the T orebody is similar to the kaolinite-anhydrite alteration elsewhere; inside the $\mathrm{T}$ orebody, the alteration is advanced argillic, with increased abundance of diaspore and decreased abundance of anhydrite.

In the most sulfide-rich samples from the high-grade zone of the $\mathrm{T}$ orebody quartz is present only as small, $100-\mu \mathrm{m}$ grains and fragments in the rock that is dominantly composed of chalcocite and pyrite (Fig. 6g). Relict quartz A or AB-type veins observed within the massive sulfide orebodies are deformed and fractured, the fractures being filled with chalcocite (Fig. 5h). In the central high-grade part of the T orebody, small veinlets of covellite cut through massive sulfide with about 

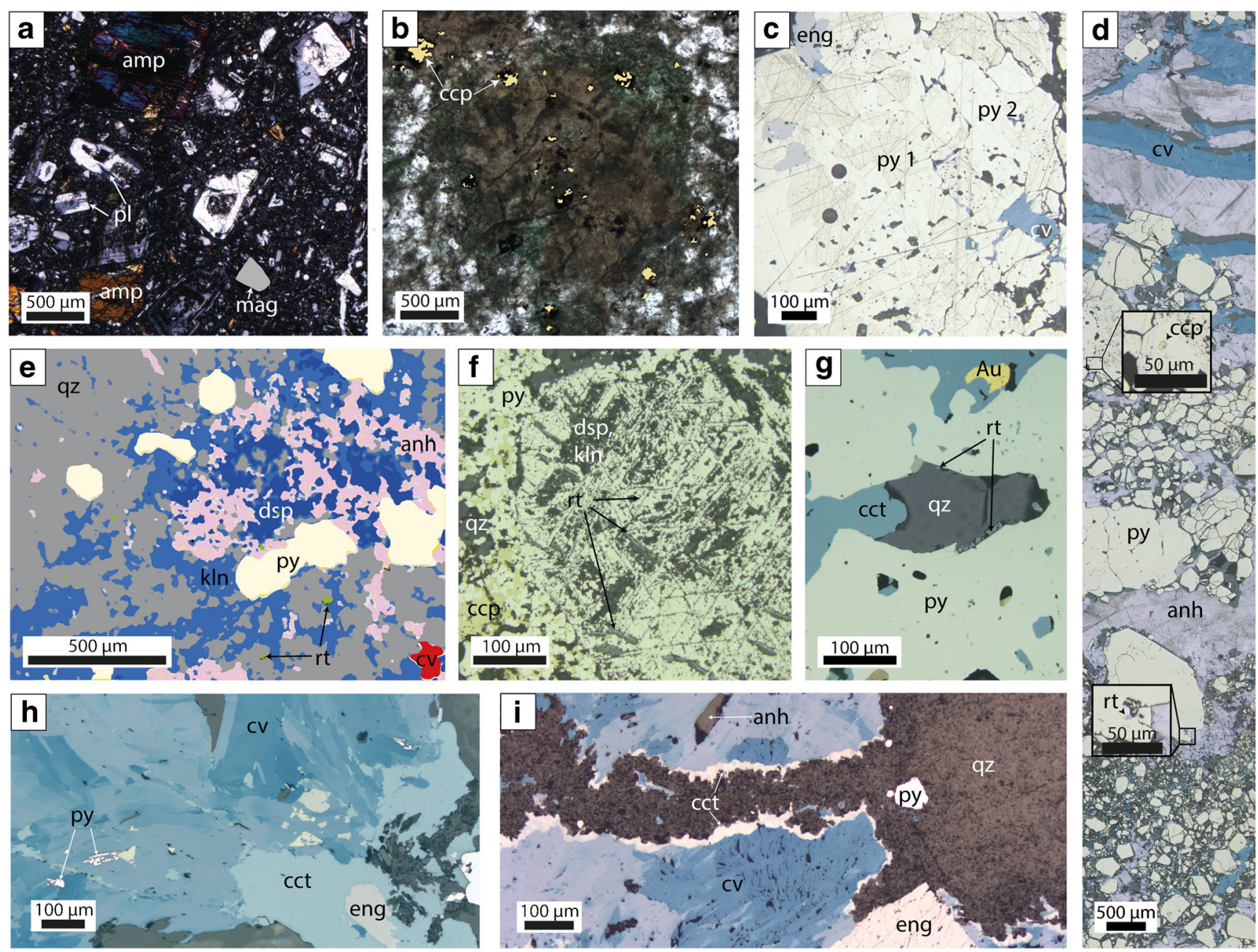

Fig. 7 Mineral paragenesis based on microscopic observations. a Leastaltered andesite with residual amphibole, plagioclase, and igneous magnetite; B67-258. b Former amphibole phenocryst altered to chloritesericite, disseminated chalcopyrite; BGM7-316. c Anhydrite-sulfide vein with two-stage pyrite, etched with concentrated $\mathrm{HNO}_{3} ; \mathrm{B} 8$ from the Tilva Ros decline at $-130 \mathrm{~m}$. d Anhydrite-sulfide vein with fragmented pyrite overgrown by anhydrite and covellite, rutile, and chalcopyrite as inclusions in pyrite; BGM1-100. e SEM phase map of texture-destructive siliceous kaolinite-anhydrite alteration with disseminated diaspore, covellite and rutile; BGM1-195. f Magnetite replaced completely by pyrite +

$30-50 \%$ residual quartz, former phenocrysts of andesite protolith replaced by pyrite with inclusions of copper sulfides and overgrown by fine-grained pyrite rim (Fig. 6f). The relict texture of magnetite phenocrysts replaced by pyrite and rutile can be seen in the sample from the T orebody's periphery (Fig. 7f). Quartz-enargite-chalcocite-covellite veinlets from the edge of the massive sulfide orebody display deformation and overgrowth of enargite by covellite and chalcocite; anhydritecovellite veins exist in the proximity to the massive sulfide deposits, and quartz-covellite-enargite veins with minor anhydrite are found in the outer margins of the T orebody (Fig. 5g). One- to 2-cm-thick veins of chalcopyrite + pyrite occur at the periphery and below the massive sulfide $\mathrm{T}$ and $\mathrm{T} 1$ orebodies. rutile along former parting planes, and a pyrite-chalcopyrite vein in the advanced argillic alteration zone at the edge of the T orebody; BA2-85.5. g Massive sulfide high-grade ore comprised of euhedral fractured pyrite set in chalcocite matrix, with rutile closely associated with residual quartz; BB4-48. h Anhydrite-sulfide veins from the kaolinite-anhydrite alteration domain, with enargite + chalcocite overgrown by covellite and fine-grained pyrite; BGM12-113.3. i Residual A or AB-type quartz vein in the massive sulfide, with enargite fractured and overgrown by covellite, minor anhydrite; BC18-40.1

The massive sulfide $\mathrm{T}$ orebody is capped by a zone of vuggy residual quartz and framed by local breccias, pervasive silicification patches, and small-scale, steep-dipping fault zones, but these faults do not seem to delineate the round shape of the body (Fig. 3b). The contact breccias are matrixsupported, monomictic, with variably altered clasts including pervasively silicified clasts, as well as clasts of andesite with phyllic-argillic alteration and bornite, chalcopyrite, and enargite (Fig. 6b); clasts of vuggy quartz occur locally. Its pores constitute around $30 \%$ by volume and are partly filled with pyrite, covellite, free-standing quartz crystals and occasional barite, alunite, anhydrite, and kaolinite. In the clasts with bornite and chalcopyrite, rare euhedral 


\begin{tabular}{|l|r|l|l|l|}
\hline Minerals & Chlorite-sericite & Quartz-sericite & $\begin{array}{c}\text { Anhydrite-kaolinite- } \\
\text { diaspore }\end{array}$ & Massive sulfide \\
\hline Magnetite & & & & \\
\hline Hematite & & & & \\
\hline Chalcopyrite & & & & \\
\hline Bornite & & & & \\
\hline Pyrite & & & & \\
\hline Rutile & & & & \\
\hline Enargite & & & & \\
\hline Chalcocite & & & & \\
\hline Covellite & & & & \\
\hline Native sulfur & & & & \\
\hline Gold & & & & \\
\hline
\end{tabular}

Fig. 8 Paragenetic sequence of porphyry-epithermal-massive sulfide system at Bor based on vein cross-cutting relationships and alteration overprinting patterns (Fig. 5), as well as microscopic evidence (Fig. 7).

enargite crystals are fractured and overgrown by bornite and chalcopyrite. Apart from the pores, vuggy quartz also exhibits ghost phenocrysts replaced by pyrite and rutile (Fig. 6e).

Observation of partially preserved drill core suggests the following mineral zonation within the T orebody (Figs. $2 \mathrm{~b}$ and 6). Bornite is observed only within clasts in a breccia in the bottom part of the $\mathrm{T}$ orebody, and also the lower part of the neighboring $\mathrm{T} 1$ orebody contains bornite + pyrite in appreciable amounts. The center of the $\mathrm{T}$ orebody is massive pyrite with covellite $>$ chalcocite. Edges of the orebody are characterized by lesser abundance of covellite, with chalcocite being the dominant copper sulfide phase. A decrease in copper grades at the edges of the $\mathrm{T}$ orebody coincides with the elevated content of pyrite. Veinlets of enargite, as well as enargite in disseminations, are observed more frequently at the edges of the orebody, while pyrite-chalcopyrite mineralization is present at the outer margins of the T orebody. Digenite is present as inclusions in the outer rims of pyrite in the highgrade, chalcocite-dominated massive sulfide.

Figure 8 summarizes the temporal overprinting relations observed at Bor at the sample to thin section scale, but despite searching, we found no large-scale structural timelines (e.g. dikes truncating veins) to exclude the possibility that this alteration evolution progressed essentially together in a single zoned hydrothermal system. As the earliest hydrothermal product, sinuous granular A-type quartz veins formed, practically free of sulfides and cross-cut by all the other vein types. Magnetite-chalcopyrite-quartz veins were probably formed due to the re-opening of the early granular A-type quartz veins (Fig. 5a) and represent the earliest mineralization contemporaneous with potassic alteration, later overprinted by chloritesericite. Chlorite-sericite alteration is overprinted first by quartz-sericite and later by kaolinite-anhydrite alteration, which is well expressed in the shallow part of Borska Reka zone between Borska Reka porphyry and Tilva Ros epithermal orebody and in the marginal parts of the T orebody,
Assemblages towards the right are seen to overprint those further left, from column to column and within each column, but local reverse relations indicate that timing might be overlapping on the mine scale

where local zones of vuggy quartz occur (Fig. 6d, e). Pyritechalcopyrite veinlets post-date quartz veins, form centerlines of AB-type veins and were probably re-opened during the later ore precipitation event, when anhydrite-sulfide veins formed. Although no clear cross-cutting relationships are observed between chalcopyrite-pyrite veins and the massive sulfide mineralization, the spatial association of breccias to the local silicification zones overprinted later by pyrite-chalcocite (Fig. 6c) and the presence of quartz-pyrite AB-type vein clasts, as well as clasts with bornite, enargite, and chalcopyrite, place the timing of these breccias after the pyritechalcopyrite \pm bornite mineralization, but before the massive pyrite-chalcocite-covellite. Relict A or AB-type quartz veins, deformed and cracked, with chalcocite filling in the cracks (Fig. $6 \mathrm{~g}$ ) are found in the high-grade part of the T orebody, and quartz-covellite-enargite veins with minor anhydrite, enargite fractured and overgrown by covellite similar to the covellite that constitutes the matrix with residual quartz (Fig. 7i) are present at the periphery, suggesting that the massive sulfide replacement overprints all other mineralization styles and represent the terminal stage of ore formation or the most distal parts of telescoped magmatic-hydrothermal system.

\section{Whole-rock geochemistry and alteration mass balance}

\section{Motivation and analytical approach}

The purpose of this section is to test whether the textural evidence for progressive massive sulfide formation by wholesale replacement of an andesitic protolith is supported by chemical mass balance, to assess the overall volume change associated with this process, and to derive bulk fluid-mineral reactions describing the main types of alteration and mineralization. Samples from the high-grade core of the T orebody and from the edges with advanced argillic alteration and a 
minimally altered andesite $900 \mathrm{~m}$ to the side of it were used for this comparison (Digital Appendix A).

Quantifying mass changes requires analyses of all major elements, including $\mathrm{Si}$ and $\mathrm{Al}$ as well as $\mathrm{Fe}$ and $\mathrm{S}$ in very different rock types, from the silicate protolith containing minor amount of sulfides to the massive sulfide-dominated sample containing only minor silicates. Such analyses are not obtained by conventional XRF bulk rock analysis nor by commercial four-acid digestion used by industry for multi-element sulfide ores, which in particular fails to provide reliable $\mathrm{Si}$ analyses. Therefore, a modified procedure for the preparation of XRF beads was used to quantify all required elements in a consistent way (Willis 2010). Approximately 50-70 g of each sample was crushed in an agate mill. A $0.5 \mathrm{~g}$ aliquot of sample powder was mixed with $1.5 \mathrm{~g}$ of $\mathrm{LiNO}_{3}$ and $6.6 \mathrm{~g}$ of $\mathrm{Li}_{2} \mathrm{O}_{4} \mathrm{~B}_{7}$ in precisely weighed proportions. The mixture was first gradually heated from 300 to $800{ }^{\circ} \mathrm{C}$ during $1 \mathrm{~h}$, to allow for complete oxidation of sulfide minerals (mostly pyrite) by the nitrate to sulfates. In the absence of a strong smell, we assume that this sulfide oxidation was complete and did not involve significant $\mathrm{H}_{2} \mathrm{~S}$ loss (Willis 2010). Subsequently, the oxidized mixture was molten and fully homogenized at $1000{ }^{\circ} \mathrm{C}$. Quenched glass beads were analyzed for major elements $(\mathrm{Si}$, $\mathrm{Ti}, \mathrm{Al}, \mathrm{Fe}, \mathrm{Mn}, \mathrm{Mg}, \mathrm{Ca}, \mathrm{Na}, \mathrm{K}, \mathrm{P}, \mathrm{S}, \mathrm{Cu}$ ) by X-ray fluorescence (XRF) using an Axios PANalytical WD-XRF spectrometer at ETH Zürich and quantified with 34 standard reference materials and an advanced matrix correction scheme implemented in the PANalytical software (Brouwer 2006). Trace elements were subsequently determined by laser ablation - inductively coupled plasma - mass spectrometry (LAICP-MS) at ETH Zürich (Switzerland) on small shards of broken glass beads, using at least 3 ablation spots of $115 \mu \mathrm{m}$ diameter, a repetition rate of $10 \mathrm{~Hz}$, and a laser energy density of $8-10 \mathrm{~J} \cdot \mathrm{cm}^{-2}$. NIST 610 glass reference material served as an external calibration standard, and the $\mathrm{TiO}_{2}$ content of the sample obtained by XRF was used as internal standard for the LA-ICP-MS traces. LA-ICP-MS intensities were processed using the MatLab-based SILLS software (Guillong et al. 2008). Concentrations of gold were taken from mine assays for the corresponding 2-m intervals to reduce the nugget effect.

This combination of XRF and LA-ICP-MS gives comparable bulk rock element concentrations even of samples with highly different matrices (Vuchkova and Jordanov 2000; Günther et al. 2001; Khokhlova et al. 2014; Ling et al. 2014). Table 1 (top) lists the analyzed concentrations of major metals and sulfur (by XRF) as well as trace elements (P, Mn by XRF, others by LA-ICP-MS). Unlike conventional silicate rock analyses, the concentrations of $\mathrm{O}, \mathrm{H}$, and the element totals cannot be readily measured and calculated, because (a) $\mathrm{Fe}$ (II) and $\mathrm{Fe}$ (III) are not measured due to pre-oxidation and (b) the weight change on ignition reflects not only $\mathrm{H}_{2} \mathrm{O}$ loss, but also oxidation of several sulfide minerals; i.e., two effects that cannot be separated by analytical methods alone. Instead, we first recalculated the analyses from wt $\%$ metals and sulfur into normative molar quantities of a set of plausible mineral components, including simplified mineral endmembers and exchange components describing solid solutions (Thompson 1982).

This norm calculation (reported in Table 1, bottom) serves two purposes. First, it allows calculation of $\mathrm{O}$ and $\mathrm{H}$ which are not available by analysis. We thereby also obtain a rough estimate of the element totals for the complex mixed silicatesulfide rocks, as reported in the corresponding three lines of Table 1 (top). These totals are well below the $100 \pm 2 \mathrm{wt} \%$ normally accepted for conventional bulk silicate rock analyses, but they are considered acceptable considering the complex rock matrices and the simplification in the choice of mineral components. For the following derivation of mass changes, we normalized the element concentrations including the estimated $\mathrm{O}$ and $\mathrm{H}$ to $1000 \mathrm{~g}$ of rock. Secondly, the mineral norm defines the amounts of minerals in the least-altered protolith, and the amounts of newly formed minerals in each of the altered rocks. These amounts delimit the quantities of minerals available as educts and products in bulk alteration reactions to be derived later.

The calculation of approximate modal mineralogy (mineral norm) from the analyzed element concentrations (in wt $\%$ concentrations) was based on the petrographically observed major minerals in each rock. Mathematically, the 10 analytically measured major element concentrations can be uniquely recalculated to 10 mineral components by base transformation, if the chosen mineral components fully describe the composition space and the bulk rock analysis is perfect, resulting in modal abundances that are all positive numbers (Thompson 1982). With complex solid solutions, mineral heterogeneities, and uncertainties in rock analysis, it may not be possible to obtain modal numbers that are all positive. To estimate realistic modal proportions listed in Table 1, we therefore iteratively modeled combinations of petrographically observed phases using the SOLVER optimization tool in Excel (Lasdon et al. 1978), which allows imposing the nonnegativity constraint and setting the deviation tolerance of idealized mineral quantities from the measured element concentrations, resulting in a number of plausible modal abundances that may be larger than 10 . To avoid introducing multiple Fe and $\mathrm{Mg}$ endmembers of ferromagnesian silicates (amphibole, biotite, chlorite), an $\mathrm{Mg}$ endmember for each mineral was used together with the exchange components $\mathrm{FeMg}_{-1}$, to satisfy mass balance without considering the distribution of the two elements among ferromagnesian solid solutions (Heinrich et al. 1995). The minerals that successfully describe the bulk composition of each rock will later be used for formulating alteration reactions in terms of the observed protolith and alteration minerals and plausible aqueous components that occur in the mineralizing fluids. For the protolith, we 


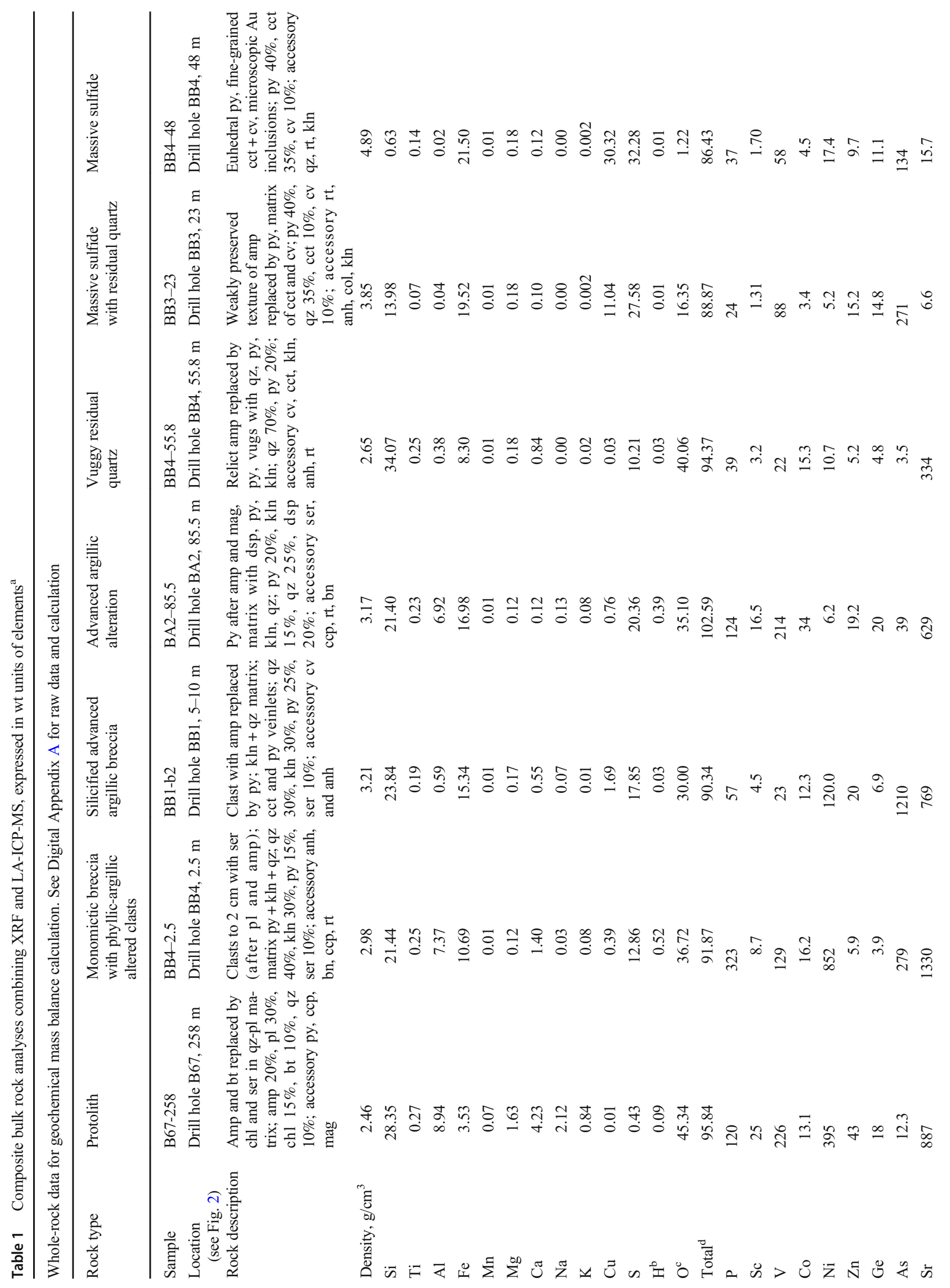




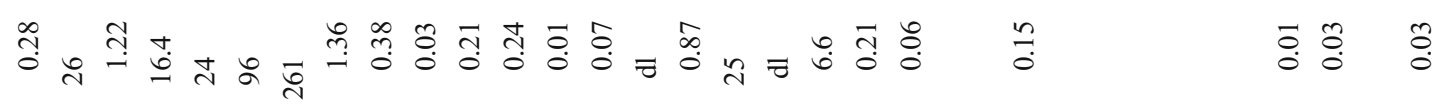

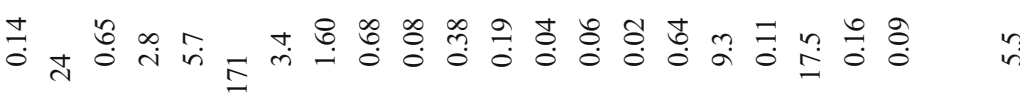

$\stackrel{0}{\circ} \stackrel{0}{\circ}$

$\stackrel{0}{0} \stackrel{0}{0}$

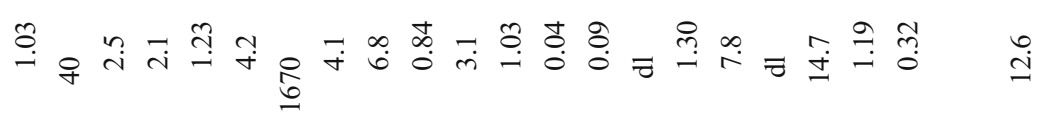

$\stackrel{0}{\check{1}}$

$\stackrel{0}{\circ} \ddot{\circ}$

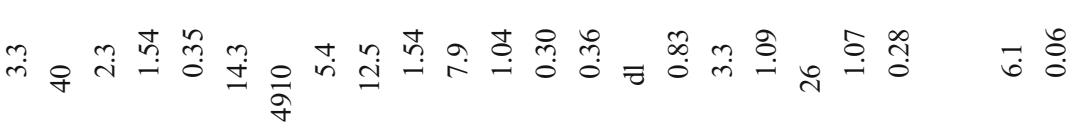

市 的

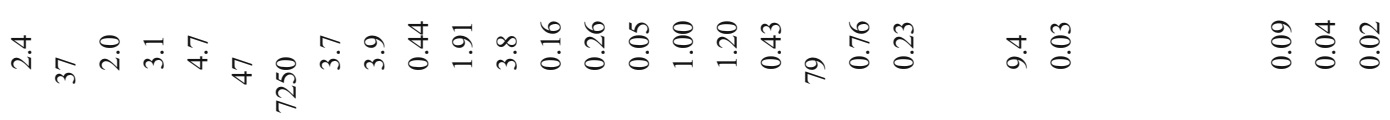

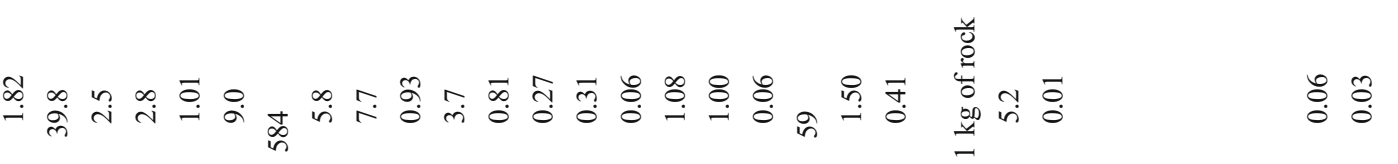

范

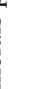

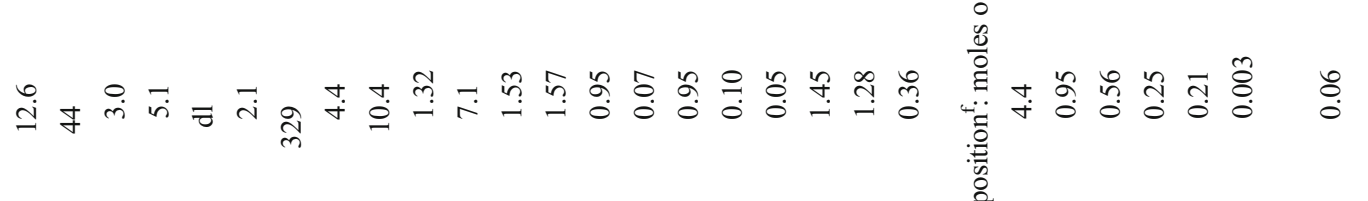




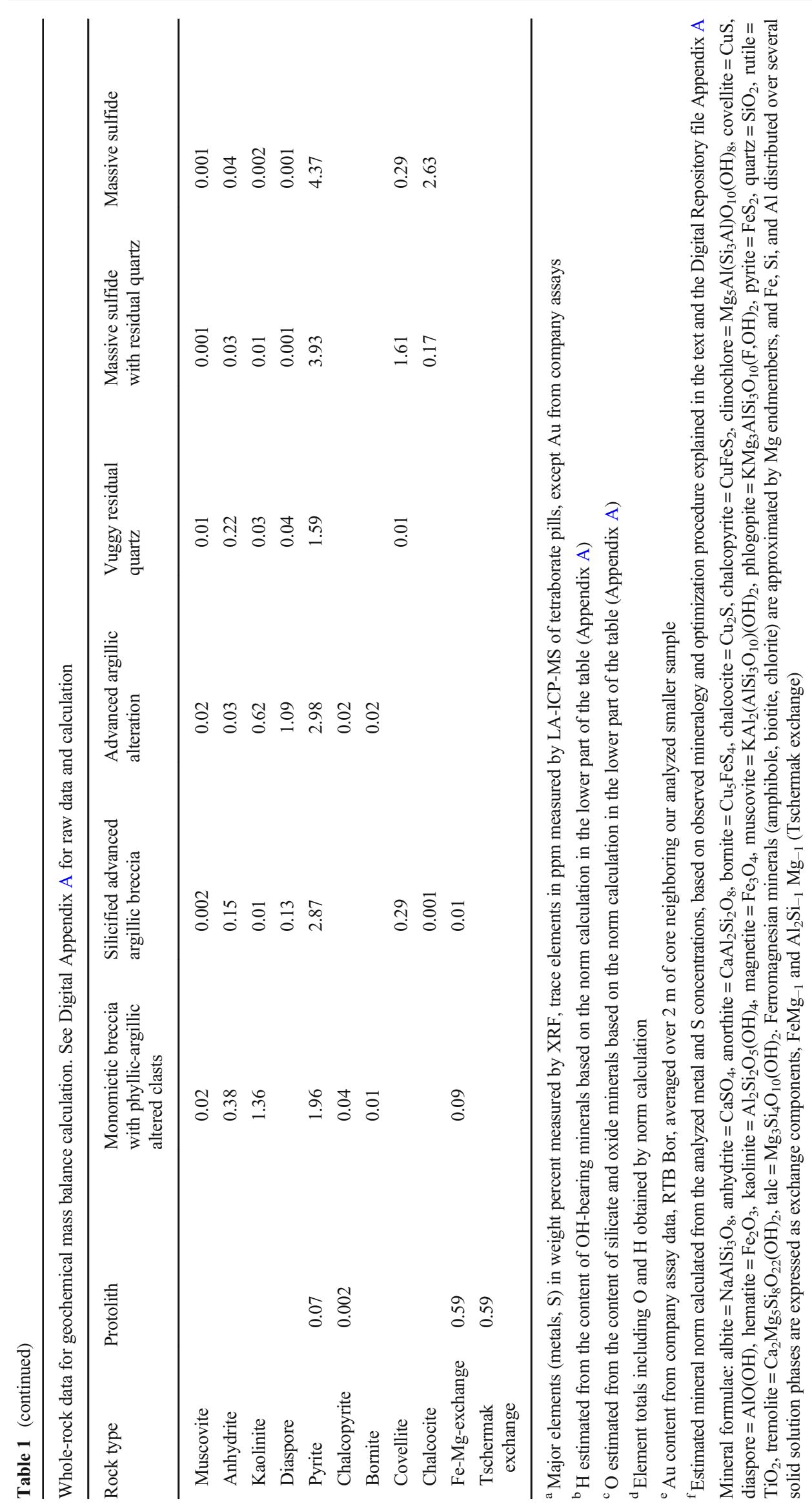



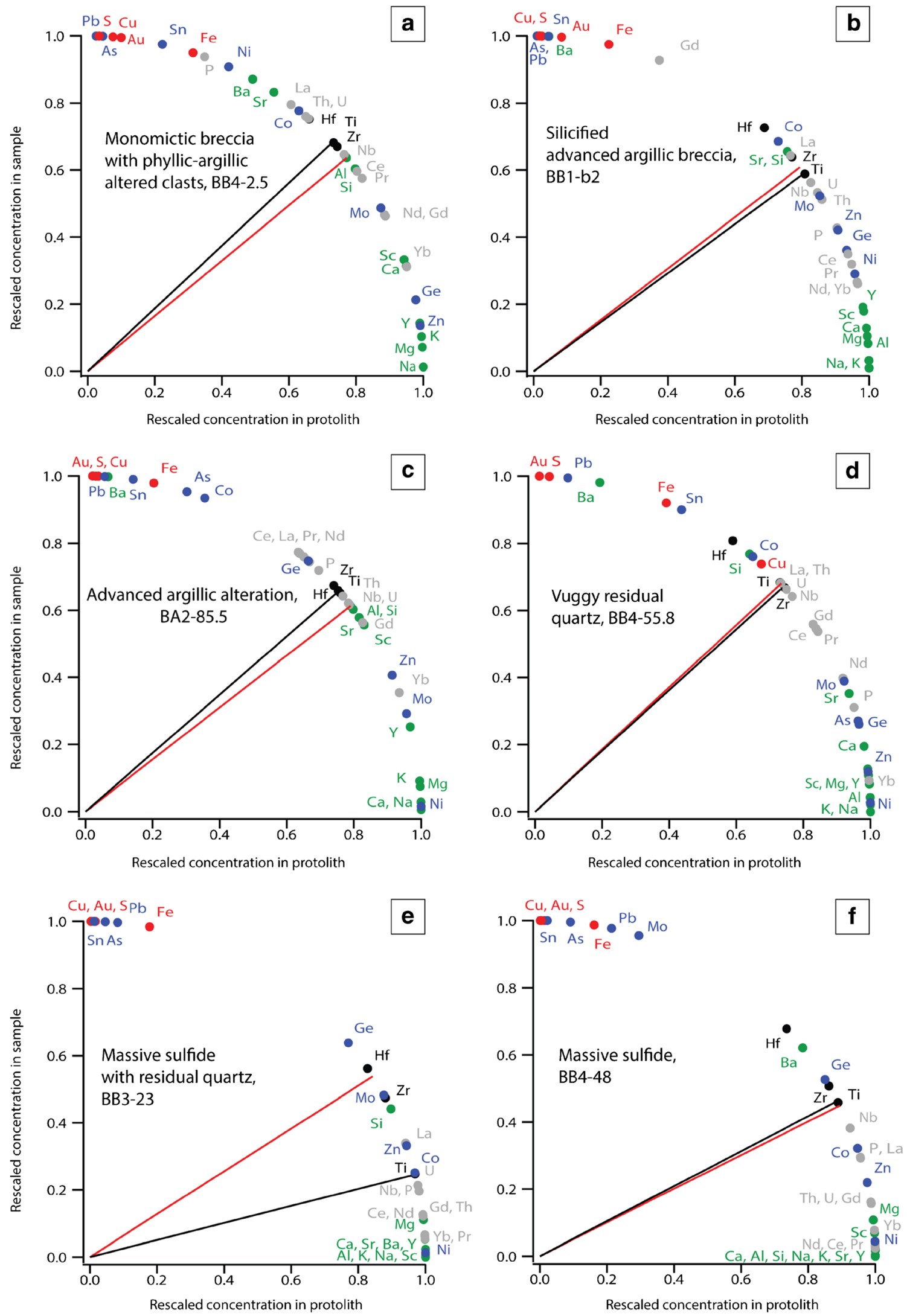
4 Fig. 9 a-f Re-scaled concentrations of major and trace elements, emphasizing main ore elements (red symbols), minor chalcophile and siderophile elements (blue), main rock-forming and lithophile elements (green), and potentially immobile trace elements (black). The black line is the reference line assuming that Ti remained conserved (Ti isocon line), the red line based on measured densities represents the reference if alteration would involve zero volume change. With $\mathrm{Ti}$ as reference assumption, elements above the black line experienced gains, elements below the line experienced loss during alteration. Rescaling is done by normalizing to the sum of squares of the measured elements: $X_{s}=\frac{X_{a}^{2}}{X_{a}^{2}+Y_{a}^{2}} ; Y_{s}=\frac{Y_{a}^{2}}{X_{a}^{2}+Y_{a}^{2}}$; where $X_{a}$ and $X_{s}$ refer to analyzed and re-scaled content of an element for the protolith, and $Y_{a}$ and $Y_{s}$ refer to analyzed and re-scaled element content for the altered sample. Each diagram also shows the reciprocal ratio of measured rock densities (red lines) to illustrate the alternative assumption of isovolumetric replacement (Gresens 1967). Assuming that Ti remained conserved, red lines above the Ti isocon (black line) indicate net volume gain, those below indicate net volume loss during alteration

choose to express the norm in terms of simplified igneous minerals, although partial alteration of amphibole to chlorite and plagioclase to kaolinite and anhydrite is observed petrographically.

\section{Gains, losses, and volume change}

We chose a modified version of the procedure of Grant (2005) to compare each altered sample on the vertical scale of the isocon diagrams in Fig. 9 with the same protolith plotted on the horizontal. This is the basis for interpreting the relative mobility of elements during the different types of alteration, including massive sulfide formation. To avoid visual bias, element concentrations were normalized to the sum of squares for each sample pair of altered rock and protolith (Humphris et al. 1998). Consequently, when plotting each normalized concentration in the altered rock against the normalized concentrations of the element in the protolith, the resulting point lies on a circle with radius 1 (Fig. 9). Elements that group closely together along this circle have maintained the same element ratio, and this can be taken as an indication that this group of elements was not significantly mobile during alteration (Grant 2005). Only a few elements occur close together along the circle for all rock pairs, but these include typically immobile $\mathrm{Ti}, \mathrm{Zr}, \mathrm{Hf}, \mathrm{U}$, and Th. Rutile is present in every altered sample, its textural character does not vary much from sample to sample; even in the massive sulfide ore with only a small amount of residual quartz, rutile is still visible as distinct grain aggregates. Therefore, in situ precipitation of rutile after magnetite and amphibole phenocrysts supports the assumption that Ti is our best approximation for a conserved component despite the widespread evidence of its mobility in the general case of high-sulfidation epithermal deposits. Whenever a Ti-bearing phase was subject to alteration and leaching, the liberated Ti precipitated as rutile and was transported at a scale not much greater than that of the original mineral grains (few $\mathrm{mm}$ or less). Zircon is the only phase that incorporates $\mathrm{Zr}$ and $\mathrm{Hf}$ in significant quantities and is also robust to alteration, but the abundance of zircon is much less than the abundance of Ti and is probably subject to greater analytical uncertainty and random scatter. We therefore selected Ti as a reference element for the calculation of gains and losses, as indicated by the reference line in the isocon plots of Fig. 9.

The two breccia types from the bottom of the $\mathrm{T}$ orebody (Fig. 9a, b) indicate close agreement between the Ti conservation and isovolumetric reference lines. The assumption of Ti immobility agrees with other candidates for immobile behavior (Hf, Zr, Th, U); i.e., the ratios among these elements did not change so that the assumption that they were all immobile is plausible. The Ti isocon line for both breccias close to the line of isovolumetric replacement is consistent with the high degree of textural preservation. Silicon is mobilized to a small degree only: slightly lost from the monomictic breccia (Fig. 9a) or slightly gained by the silicified advanced argillic breccia (Fig. 9b). Aluminum is approximately conserved in the monomictic breccia but severely lost from the silicified advanced argillic breccia. Major alkali and earth alkali elements were significantly depleted during alteration of both breccias, whereas $\mathrm{Cu}, \mathrm{S}, \mathrm{Au}$, and a number of minor ore elements ( $\mathrm{Pb}, \mathrm{As}, \mathrm{Sn}$, and also $\mathrm{Fe}$ ) were consistently gained as precipitating sulfide minerals, consistent with abundant disseminated pyrite and the economic ore grade of these rocks $(0.6$ and $1.7 \% \mathrm{Cu}, \sim 1 \mathrm{ppm} \mathrm{Au})$.

Advanced argillic alteration sample and vuggy residual quartz (Fig. 9c, d) are also characterized by close correspondence between the location of the Ti reference line, comparable ratios to weakly mobile $\mathrm{Th}, \mathrm{U}, \mathrm{Zr}$, and $\mathrm{Hf}$, as well as the constant volume line. In the vuggy residual quartz sample (Fig. 9d), only gold and pyrite $(\mathrm{Fe}, \mathrm{S})$ are visibly enriched, while all other ore-forming metals are either insignificantly enriched (notably $\mathrm{Cu}$ ) or even depleted (As). Silicon plots close to the isocon line in the advanced argillic alteration sample (Fig. 9c) but is significantly enriched in the vuggy residual quartz sample (Fig. 9d). Aluminum is conserved in the advanced argillic alteration sample but is lost, together with all other rock-forming elements other than $\mathrm{Si}$, in the vuggy residual quartz sample.

Massive sulfide samples (Fig. 9e, f) show the greatest deviation of the constant volume line from the Ti reference line (Fig. 9e), as well as the largest scatter of other potentially immobile Th, U, Zr, and Hf (Fig. 9e, f). Nevertheless, Ti conservation is the most plausible reference considering the textural preservation of rutile clusters even in these extremely altered rocks (Fig. 7f and g). Si and $\mathrm{Zn}$, as well as $\mathrm{Zr}$, plot between the Ti reference line and the constant volume line in the massive sulfide sample with a significant amount of residual quartz (Fig. 9e). All ore-forming elements are enriched, which is illustrated by large amount of copper sulfides, dominantly covellite for the massive sulfide sample with residual quartz, and chalcocite in the case of truly massive sulfide sample, consistent with extremely high copper and gold 
grades (11 and $30 \% \mathrm{Cu}, 9$ and $25 \mathrm{ppm} \mathrm{Au})$. Most rockforming elements are extremely depleted (Fig. 9e), in line with the complete destruction of rock-forming minerals. Massive sulfide with only small amount of residual quartz displays a coincidence between the constant volume line and the Ti reference line; $\mathrm{Zr}$ plots close to the isocon, but $\mathrm{Hf}, \mathrm{Th}$, and $\mathrm{U}$ deviate from both reference lines (Fig. 9f). Main rock-forming elements are depleted in the same manner as for the massive sulfide with residual quartz, except that $\mathrm{Si}$ is completely lost in the truly massive sulfide sample together with other rockforming elements (Fig. 9f).

Assuming the conservation of Ti, gains and losses for each element during each type of alteration were calculated according to the formula (Grant 2005):

$\Delta C=\left(C_{\text {immobile }}^{P}-C_{\text {immobile }}^{A}\right) \cdot C^{A}-C^{P}$

where $C^{P}$ is the concentration of element in the least-altered protolith, and $C^{A}$ is the concentration in the altered sample. All altered and mineralized samples are compared to the fresh andesite protolith, on the initial assumption that each is derived directly from the same andesite. The resulting gains or losses (positive or negative $\Delta C$ ) of each mobile element are initially expressed in weight percent of major or in ppm of trace elements (Table 1).

\section{Bulk fluid-rock reactions}

Mass gains and losses in units of elements (or oxides such as $\mathrm{Na}_{2} \mathrm{O}$ ) are far from a geologically realistic description of fluidrock reaction, which in reality involves mineral phases in the rock and aqueous components in the fluid. In this section, we therefore recalculate the mass balance results of Table 1 into more plausible bulk fluid-mineral reactions, using the minerals that make up the norms of the protolith and the variably altered rocks (Table 1) and a set of simplified aqueous components (cf. Heinrich et al. 1995; Ulrich and Heinrich 2002; Halley 2020). All reactions are expressed in mole units and scaled to changes experienced by $1 \mathrm{~kg}$ of protolith.

The stoichiometric coefficient $\Delta \mathrm{N}_{\min }{ }^{\mathrm{R}}$ of each mineral component (subscript min) in the reaction $\mathrm{R}$ is the difference between the molar abundance of each mineral making up the altered rock (A), minus the corresponding moles making up the protolith $(\mathrm{P})$, whereby the altered rock is scaled to preserve the total quantity of $\mathrm{Ti}$, assumed to be conserved:

$\Delta N_{\min }^{R}=\left(\frac{C_{T i}^{A}}{C_{T i}^{P}} \cdot N_{\min }^{A}\right)-N_{\min }^{P}$

Thus, minerals only existing in the protolith are completely consumed, and their abundance in the protolith equals their stoichiometric coefficient on the left-hand side (educts) of the reaction. Conversely, minerals only present in the altered rock appear on the right-hand side (products) of the reaction, with stoichiometric coefficients corresponding to their abundance in the new rock, scaled to constant Ti. The digital Appendix A explains the details of the calculation and includes a forward calculation of gains and losses in weight $\%$ of elements, to check the accuracy in terms of the analyzed concentrations (Eq. 2).

The aqueous reaction partners represent gains by the reacting fluid compensating the element losses experienced by the reacting rock. Conversely, element gains by the rock must be provided by the fluid, which therefore experiences a corresponding loss of elements. The stoichiometric coefficients of the chosen aqueous species are calculated by converting the gains and losses in grams of analyzed elements per 1000-g protolith (Eq. 1) to the corresponding molar quantities, using the same matrix inversion as used in the norm calculations of mineral components (see Appendix A). As aqueous solutions containing ionic components need to be charge-balanced, an additional element must be included to constrain this base transformation, i.e., electrons. Alternatively, we here use neutral species including chloride salts for most metals that are chloride-complexed in saline solutions, thus requiring $\mathrm{Cl}$ as additional, conserved component. We introduce $\mathrm{HCl}$ as the charge-compensating aqueous component, which provides a useful measure of net acid gain or loss attending alteration. This acid balance includes the hydrolysis of anhydrous minerals such as $\mathrm{K}$-feldspar to $\mathrm{OH}$-bearing minerals such as muscovite and kaolinite, as well as the net acidity produced by any metal precipitation reaction (cf. Hemley and Hunt 1992; Reed et al. 2013). Sulfate and sulfide are the likely dominant pair of oxidized and reduced species in the fluid and we therefore use $\mathrm{H}_{2} \mathrm{SO}_{4}$ and $\mathrm{H}_{2} \mathrm{~S}$ as aqueous components to account for redox balance. Total sulfate and sulfide in the fluid thus express the net redox changes among Fe-silicates of variable Fe valency and of sulfates and sulfides in the rock (Drummond and Ohmoto 1985; Giggenbach 1992; Ohmoto and Goldhaber 1997).

To obtain stoichiometrically balanced reactions, we calculate gains and losses based on the idealized composition that correspond exactly to the mineral norm. Appendix A contains an extra sheet for the sample pair BB4-2.5/B67-258 to demonstrate that deviations never exceed 5\% of the analyzed concentration of each element. Nevertheless, some reactions appear slightly unbalanced on their last digit of stoichiometric coefficients, due to rounding (correct values see Appendix A).

For simplicity, minor $\mathrm{Mn}$ and $\mathrm{P}$ were omitted. Mn is smaller than the likely analytical uncertainty of major element concentrations, but is consistently lost during all alteration types. Phosphorus is contained in apatite, which occurs in the heavy mineral fraction but was not seen in thin section; it is lost from most alteration types, except for the monomictic breccia with phyllic-argillic altered clasts (BB4-2.5), where gain of $\mathrm{P}$ potentially indicates the presence of alunite or some undetected aluminum-phosphate-sulfate minerals. In the following, we will present each bulk reaction obtained in this manner and assess its geological significance with regard to major reaction partners. 
Table 2 Gains and losses of mineralized samples in comparison to weakly altered andesite protolith

\begin{tabular}{|c|c|c|c|c|c|c|}
\hline Rock type & $\begin{array}{l}\text { Monomictic breccia } \\
\text { with phyllic-argillic } \\
\text { altered clasts }\end{array}$ & $\begin{array}{l}\text { Silicified advanced } \\
\text { argillic breccia }\end{array}$ & $\begin{array}{l}\text { Advanced argillic } \\
\text { alteration }\end{array}$ & $\begin{array}{l}\text { Vuggy residual } \\
\text { quartz }\end{array}$ & $\begin{array}{l}\text { Massive sulfide } \\
\text { with residual quartz }\end{array}$ & Massive sulfide \\
\hline Sample pair & BB4-2.5 / B67-258 & $\mathrm{BB} 1-\mathrm{b} 2 / \mathrm{B} 67-258$ & BA2-85.5/B67-258 & BB4-55.8/B67-258 & BB3-23/B67-258 & BB4-48/B67-258 \\
\hline $\mathrm{Si}$ & -60 & 56 & -23 & 78 & 276 & -280 \\
\hline $\mathrm{Ti}$ & 0 & 0 & 0 & 0 & 0 & 0 \\
\hline $\mathrm{Al}$ & -14.7 & -85.0 & -9.2 & -89.3 & -91.4 & -92.9 \\
\hline $\mathrm{Fe}$ & 82 & 183 & 175 & 55 & 756 & 390 \\
\hline $\mathrm{Mg}$ & -15.9 & -14.7 & -15.7 & -15.2 & -10.2 & -13.9 \\
\hline $\mathrm{Ca}$ & -27 & -34 & -41 & -33 & -38 & -40 \\
\hline $\mathrm{Na}$ & -22 & -21 & -20 & -22 & -22 & -22 \\
\hline $\mathrm{K}$ & -7.5 & -8.2 & -7.4 & -8.2 & -8.3 & -8.3 \\
\hline $\mathrm{Cu}$ & 4.2 & 24 & 9.1 & 0.22 & 449 & 614 \\
\hline $\mathrm{S}$ & 140 & 252 & 242 & 109 & 1117 & 649 \\
\hline $\mathrm{H}$ & 4.9 & -0.5 & 3.8 & -0.6 & -0.6 & -0.8 \\
\hline $\mathrm{O}$ & -61 & -43 & -47 & -27 & 192 & -448 \\
\hline $\mathrm{P}$ & 227 & -59.0 & 13.7 & -78 & -94 & -80 \\
\hline Sc & -15.3 & -19.8 & -6.9 & -21 & -23 & -23 \\
\hline $\mathrm{V}$ & -88 & -201 & 3.8 & -202 & -132 & -164 \\
\hline Co & 4.3 & 0.15 & 24 & 3.4 & -9.4 & -8.3 \\
\hline $\mathrm{Ni}$ & 521 & -266 & -388 & -383 & -389 & -376 \\
\hline $\mathrm{Zn}$ & -37 & -22 & -23 & -38 & -27 & -33 \\
\hline $\mathrm{Ge}$ & -13.7 & -10.4 & 3.8 & -12.7 & -1.9 & -6.0 \\
\hline As & 288 & 1290 & 30 & -8.6 & 279 & 132 \\
\hline $\mathrm{Sr}$ & 543 & -60 & -211 & -530 & -880 & -870 \\
\hline $\mathrm{Y}$ & -10.6 & -9.9 & -9.0 & -11.4 & -12.4 & -12.3 \\
\hline $\mathrm{Zr}$ & -1.42 & -4.8 & -0.92 & -1.58 & -18.6 & -16.2 \\
\hline $\mathrm{Nb}$ & -0.27 & -0.79 & -0.44 & -0.30 & -2.3 & -1.65 \\
\hline Mo & -2.0 & -1.72 & -3.4 & -2.8 & -2.1 & 12.6 \\
\hline $\mathrm{Sn}$ & 7.6 & 49 & 13.3 & 2.5 & 181 & 101 \\
\hline $\mathrm{Ba}$ & 300 & 7460 & 4950 & 1470 & -326 & -49 \\
\hline $\mathrm{La}$ & 1.83 & -0.43 & 1.39 & 0.002 & -2.7 & -3.0 \\
\hline $\mathrm{Ce}$ & -2.1 & -6.2 & 3.1 & -3.1 & -9.6 & -10.0 \\
\hline $\operatorname{Pr}$ & -0.32 & -0.84 & 0.33 & -0.41 & -1.23 & -1.28 \\
\hline $\mathrm{Nd}$ & -3.1 & -5.0 & 1.42 & -3.8 & -6.7 & -6.8 \\
\hline $\mathrm{Gd}$ & -0.66 & 2.5 & -0.41 & -0.42 & -1.33 & -1.27 \\
\hline $\mathrm{Yb}$ & -0.62 & -0.67 & -0.56 & -0.86 & -0.88 & -0.87 \\
\hline $\mathrm{Hf}$ & 0.21 & 0.13 & -0.06 & 0.45 & -0.26 & -0.01 \\
\hline $\mathrm{Au}$ & 0.98 & 1.19 & 3.4 & 8.3 & 9.9 & 27 \\
\hline $\mathrm{Pb}$ & 62 & 84 & 26 & 14.3 & 17.4 & 5.7 \\
\hline Th & 0.33 & -0.46 & -0.13 & 0.01 & -1.10 & -1.05 \\
\hline $\mathrm{U}$ & 0.08 & -0.12 & -0.06 & -0.02 & -0.26 & -0.30 \\
\hline
\end{tabular}

Gains (positive values) and losses (negative) of major elements and trace elements in comparison to the protolith sample B67-258

Major elements in grams, trace elements in $\mu \mathrm{g}$ per $1 \mathrm{~kg}$ of protolith

Monomictic breccia with phyllic-argillic altered clasts (BB42.5) This breccia from the edge of the $T$ orebody was formed by the destruction of magmatic amphibole + biotite + plagioclase with intermediate $\mathrm{Ab} / \mathrm{An}$ (andesine-labradorite) to a slightly smaller volume of denser rock in which quartz + pyrite + kaolinite formed together with anhydrite, chlorite, and minor chalcopyrite. This alteration involved a slight removal of $\mathrm{Si}$ and $\mathrm{Al}$ but required a major introduction of $\mathrm{FeCl}_{2}$ (Fig. 9a). It also 
required input of oxidized, as well as reduced sulfur and acidity, whereas most of the alkali and earth alkali metals were lost as chloride salts (Fig. 9a), apart from the small fraction of Ca incorporated into anhydrite. The net introduction of $\mathrm{HCl}$, but stoichiometric loss of $\mathrm{H}_{2} \mathrm{O}$, means that the increase in contained water bound in kaolinite was mainly due to hydrolysis of less hydrous igneous minerals (cation exchange), requiring an acid fluid that also is capable of net $\mathrm{Al}$ removal. Even though the rock experienced the formation of $1.4 \mathrm{~mol}$ of quartz, the production of $\mathrm{SiO}_{2, \text { aq }}$ was somewhat larger at $2.1 \mathrm{~mol}$, as observed by the net Si loss during destruction of the magmatic silicate minerals (Table 2, Fig. 9a). The rock changed from almost barren to low economic ore grade with net addition of $\mathrm{Cu}$ to form chalcopyrite, consistent with petrography.
$1000 \mathrm{~g}$ or $407 \mathrm{~cm}^{3}$ of andesite protolith with $\rho=2.46 \mathrm{~g} / \mathrm{cm}^{3}$

0.249 Trem $+0.938 \mathrm{Ab}+$ $0.558 \mathrm{An}+0.214 \mathrm{Phl}+$ $0.003 \mathrm{Mt}+0.496 \mathrm{FeMg}_{-1}+$ $0.588 \mathrm{Al}_{2} \mathrm{Si}_{-1} \mathrm{Mg}_{-1}+$

$1.471 \mathrm{FeCl}_{2}+0.066 \mathrm{CuCl}+$ $3.475 \mathrm{H}_{2} \mathrm{~S}+0.879 \mathrm{H}_{2} \mathrm{SO}_{4}+$ $0.761 \mathrm{HCl}$
$1019 \mathrm{~g}$ or $342 \mathrm{~cm}^{3}$ monomictic breccia with phyllic-argillic altered clasts, BB4-2.5 with $\rho=2.98 \mathrm{~g} / \mathrm{cm}^{3}$

$\rightarrow 0.03 \mathrm{Clnchl}+0.392 \mathrm{Anh}+$ $1.386 \mathrm{~K} \ln +1.932 \mathrm{Py}+$ $0.022 \mathrm{Mus}+0.929 \mathrm{Qtz}+$ $0.039 \mathrm{Ccp}+0.005 \mathrm{Bn}+$ $2.122 \mathrm{SiO}_{2, \mathrm{aq}}+0.545 \mathrm{Al}(\mathrm{OH})_{3}+$ $0.654 \mathrm{MgCl}_{2}+$ $0.665 \mathrm{CaCl}_{2}+0.938 \mathrm{NaCl}+$ $0.192 \mathrm{KCl}+1.467 \mathrm{H}_{2} \mathrm{O}$
$\mathrm{Ni}$ and $\mathrm{Co}$ are enriched in the mildly altered rocks, by transfer from igneous minerals to relatively minor pyrite under acid-neutralizing conditions (Fig. 9a); Mo and $\mathrm{Zn}$ experienced a net loss. Loss of $\mathrm{Zn}$ in this sample and in all other samples from the $\mathrm{T}$ orebody is probably due to elevated level of $\mathrm{Zn}$ that is explained by weak chlorite alteration of the protolith; overprinting of chlorite by other alteration types would result in the destruction of chlorite and $\mathrm{Zn}$ loss. Minor and trace element composition changes include the addition of $\mathrm{P}, \mathrm{Ba}$, and $\mathrm{Sr}$ (Table 2, Fig. 9a), which may be incorporated into anhydrite. Many lithophile trace elements including most REE, experienced net loss, probably by the destruction of igneous minerals, especially magnetite, without the formation of new host accessories. Gain of P and simultaneous loss of most REE can be explained by the formation of minor aluminum-phosphate-sulfate minerals not identified in the sample but common in Bor (Janković et al. 2002).

Silicified advanced argillic breccia (BB1-b2) This breccia is formed by converting the protolith into a denser rock, which occupies almost the same volume due to net mass gain. Ore formation is expressed by the production of larger amount of chalcopyrite and pyrite compared to the monomictic breccia with phyllic-argillic altered clasts BB4-2.5 and is accompanied by smaller amounts of anhydrite formed and more significant loss of $\mathrm{Al}$. This alteration requires further addition of oxidized and reduced sulfur as well as $\mathrm{FeCl}_{2}$. The $\mathrm{Cu}-\mathrm{Fe}$ - sulfide addition and net oxidation of the rock by sulfuric acid are accompanied by liberation of additional $\mathrm{HCl}$ into the fluid.
$1000 \mathrm{~g}$ or $407 \mathrm{~cm}^{3}$ of andesite protolith with $\rho=2.46 \mathrm{~g} / \mathrm{cm} 3$

0.249 Trem $+0.908 \mathrm{Ab}+$ $0.558 \mathrm{An}+0.214 \mathrm{Phl}+$ $0.003 \mathrm{Mt}+0.002 \mathrm{Ccp}+$ $0.578 \mathrm{FeMg}_{-1}+$ $0.588 \mathrm{Al}_{2} \mathrm{Si}_{-1} \mathrm{Mg}_{-1}+$ $1.998 \mathrm{SiO}_{2, \text { aq }}+$ $3.27 \mathrm{FeCl}_{2}+0.381 \mathrm{CuCl}+$ $6.663 \mathrm{H}_{2} \mathrm{~S}+1.18 \mathrm{H}_{2} \mathrm{SO}_{4}$
$1304 \mathrm{~g}$ or $406 \mathrm{~cm}^{3}$ silicified advanced argillic breccia, BB1-b2 with $\rho=3.21 \mathrm{~g} / \mathrm{cm} 3$

$\rightarrow 0.024 \mathrm{Clnchl}+0.197 \mathrm{Anh}+$ $0.015 \mathrm{~K} \ln +0.174 \mathrm{Dia}+$ 0.003 Mus + 3.635 Py + $7.776 \mathrm{Qtz}+0.112 \mathrm{Hem}+$ $0.38 \mathrm{Cv}+0.001 \mathrm{Cc}+$ $3.152 \mathrm{Al}(\mathrm{OH})_{3}+0.604 \mathrm{MgCl}_{2}+$ $0.86 \mathrm{CaCl}_{2}+0.908 \mathrm{NaCl}+$ $0.211 \mathrm{KCl}+1.926 \mathrm{H}_{2} \mathrm{O}+$ $2.875 \mathrm{HCl}$
$\mathrm{As}, \mathrm{Pb}$, and $\mathrm{Sn}$ are significantly enriched and are probably incorporated into pyrite and covellite; Co shows weak enrichment, and Mo is lost in this sample. Loss of $\mathrm{P}$ accompanied by loss of $\mathrm{Ca}$, as well as most REE, can indicate destruction of igneous apatite, and gains of minor chalcophile elements are reflected by a more pronounced sulfide enrichment of this breccia compared to the BB4-2.5 sample (Fig. 9b).

Advanced argillic alteration (BA2-85.5) This sample is formed by almost complete replacement of former hornblende and biotite phenocrysts by quartz, pyrite, sericite, and kaolinite + diaspore, with a smaller amount of anhydrite compared to what is found in the breccias, as well as the complete destruction of magnetite. The resulting volume differs from the protolith by $3 \%$, due to the effect of counterbalancing the mass gains expressed in formation of denser minerals like $\mathrm{Cu}$ sulfides and diaspore. This alteration requires the addition of both oxidized and reduced sulfur, but sees losses of $\mathrm{H}_{2} \mathrm{O}$ and $\mathrm{HCl}$ due to the drastic amounts of rock-forming elements that need to be removed in the form of chloride complexes, which prevails compared to the addition of ore-forming element chlorides.

\begin{tabular}{|c|c|c|}
\hline $\begin{array}{l}1000 \mathrm{~g} \text { or } 407 \mathrm{~cm}^{3} \text { of andesite } \\
\text { protolith with } \rho=2.46 \mathrm{~g} / \mathrm{cm} 3\end{array}$ & & $\begin{array}{l}1262 \mathrm{~g} \text { or } 399 \mathrm{~cm}^{3} \text { advanced } \\
\text { argillic alteration, BA2-85.5 with } \\
\rho=3.17 \mathrm{~g} / \mathrm{cm} 3\end{array}$ \\
\hline $\begin{array}{l}0.249 \mathrm{Trem}+0.881 \mathrm{Ab}+ \\
0.558 \mathrm{An}+0.214 \mathrm{Phl}+ \\
0.003 \mathrm{Mt}^{+} 0.59 \mathrm{FeMg}_{-1}+ \\
0.588 \mathrm{Al}_{2} \mathrm{Si}_{-1} \mathrm{Mg}_{-1}+ \\
3.141 \mathrm{FeCl}_{2}+0.142 \mathrm{CuCl}+ \\
6.598 \mathrm{H}_{2} \mathrm{~S}+0.964 \mathrm{H}_{2} \mathrm{SO}_{4}\end{array}$ & & $\begin{array}{l}\text { 0.013 Clnchl + 0.036 Anh + } \\
0.785 \mathrm{Kln}+1.374 \mathrm{Dia}+ \\
0.025 \mathrm{Mus}+3.689 \mathrm{Py}+ \\
3.317 \mathrm{Qtz}+0.028 \mathrm{Ccp}+ \\
0.023 \mathrm{Bn}+0.807 \mathrm{SiO}_{2, \mathrm{aq}}+ \\
0.342 \mathrm{Al}(\mathrm{OH})_{3}+0.648 \mathrm{MgCl}_{2}+ \\
1.021 \mathrm{CaCl}_{2}+0.881 \mathrm{NaCl}+ \\
0.189 \mathrm{KCl}+4.171 \mathrm{H}_{2} \mathrm{O}+ \\
2.017 \mathrm{HCl}\end{array}$ \\
\hline
\end{tabular}

All minor chalcophile elements except $\mathrm{Zn}$ show considerable enrichment; Mo is moderately depleted, and $\mathrm{Ni}$ is lost completely. Minor gain of Co (Table 2) can reflect its incorporation into pyrite that developed after magnetite (Fig. 9c), or 
into chalcopyrite. Moderate enrichment of $\mathrm{P}$ is similar to the enrichment of $\mathrm{Ce}, \mathrm{La}, \mathrm{Pr}$, and $\mathrm{Nd}$.

Vuggy residual quartz (BB4-55.8) In this sample, the effect of leaching of original plagioclase and hornblende phenocrysts and formation of vugs is partly counterbalanced by the increased amount of pyrite, illustrating the close-toisovolumetric replacement of the andesite protolith. Based on the following reaction of converting the protolith to vuggy residual quartz, the required addition of $\mathrm{SiO}_{2}$ is not large: conversion of the matrix of the protolith to quartz serves as the most important source of silica, which is accompanied by complete destruction of all rock-forming minerals and removal of alkalis, $\mathrm{Ca}$ and $\mathrm{Al}$ into solution. The addition of reduced sulfur is necessary, as well as acidity, to leach all the rockforming oxides and leave the carcass of residual quartz with pyrite and kaolinite. Net addition of water is insignificant, which shows that for this pair of samples all the hydroxides that were contained in the rock-forming minerals could be incorporated into kaolinite or else required for the removal of $\mathrm{Al}$.

\begin{tabular}{|c|c|c|}
\hline $\begin{array}{l}1000 \mathrm{~g} \text { or } 407 \mathrm{~cm}^{3} \text { of andesite } \\
\text { protolith with } \rho=2.46 \mathrm{~g} / \mathrm{cm} 3\end{array}$ & & $\begin{array}{l}1047 \mathrm{~g} \text { or } 395 \mathrm{~cm}^{3} \text { Vuggy } \\
\text { residual quartz, BB4-55.8 with } \\
\rho=2.65 \mathrm{~g} / \mathrm{cm} 3\end{array}$ \\
\hline $\begin{array}{l}0.249 \mathrm{Trem}+0.951 \mathrm{Ab}+ \\
0.558 \mathrm{An}+0.214 \mathrm{Phl}+ \\
0.003 \mathrm{Mt}+0.002 \mathrm{Ccp}+ \\
0.59 \mathrm{FeMg}_{-1}+ \\
0.588 \mathrm{Al}_{2} \mathrm{Si}_{-1} \mathrm{Mg}_{-1}+ \\
2.783 \mathrm{SiO}_{2, \mathrm{aq}}+0.985 \mathrm{FeCl}_{2}+ \\
0.004 \mathrm{CuCl}+2.779 \mathrm{H}_{2} \mathrm{~S}+ \\
0.201 \mathrm{H}_{2} \mathrm{O}+0.622 \mathrm{H}_{2} \mathrm{SO}_{4}+ \\
2.101 \mathrm{HCl}\end{array}$ & $\rightarrow$ & $\begin{array}{l}\text { 0.017 Clnchl + 0.225 Anh + } \\
0.029 \mathrm{Kln}+0.04 \mathrm{Dia}+ \\
0.005 \mathrm{Mus}+1.587 \mathrm{Py}+ \\
\text { 8.677 Qtz }+0.006 \mathrm{Cv}+ \\
3.308 \mathrm{Al}(\mathrm{OH})_{3}+0.626 \mathrm{MgCl}_{2}+ \\
0.832 \mathrm{CaCl}_{2}+0.951 \mathrm{NaCl}+ \\
0.209 \mathrm{KCl}\end{array}$ \\
\hline
\end{tabular}

Virtually all minor chalcophile and siderophile elements are depleted, with notable exceptions of $\mathrm{Sn}, \mathrm{Pb}$, and $\mathrm{Co}$ (Fig. 9d). All trace elements are lost, reflecting the leaching of pyrite-enriched rock by highly reactive, corrosive fluid that left nothing behind but vuggy residual quartz with significant amount of pyrite and minor amount of copper sulfides.

Massive sulfide with residual quartz (BB3-23) This high-grade massive sulfide sample is formed by bringing most of the rock-forming elements except Si into solution, except for the small amount taken up by talc and muscovite. Talc is not observed petrographically, but is arbitrarily introduced as a possible mineral phase that could incorporate the minor amount of analyzed $\mathrm{Mg}$. Added sulfur is predominantly in the reduced form, and both $\mathrm{HCl}$ and $\mathrm{H}_{2} \mathrm{O}$ losses are required to balance the effect of addition of ore metals as chloride complexes and to bring $\mathrm{Al}$ into solution. The net gain of $\mathrm{Si}$ in this sample is higher than in the vuggy residual quartz sample, suggesting net silicification in addition to filling of the vuggy quartz carcass with $\mathrm{Cu}$ and $\mathrm{Fe}$ sulfides. However,

this sample displays maximum deviation of the Ti conservation line from the constant volume line, which is closer to $\mathrm{Zr}$ (Fig. 9e), suggesting that $\mathrm{Ti}$ is not entirely conserved on a local scale.

$1000 \mathrm{~g}$ or $407 \mathrm{~cm}^{3}$ of andesite protolith with $\rho=2.46 \mathrm{~g} / \mathrm{cm} 3$

0.249 Trem $+0.951 \mathrm{Ab}+$ $0.558 \mathrm{An}+0.214 \mathrm{Phl}+$ $0.003 \mathrm{Mt}+0.002 \mathrm{Ccp}+$ $0.59 \mathrm{FeMg}_{-1}+$ $0.588 \mathrm{Al}_{2} \mathrm{Si}_{-1} \mathrm{Mg}_{-1}+$ $9.815 \mathrm{SiO}_{2, \mathrm{aq}}+$ $13.543 \mathrm{FeCl}_{2}+7.062 \mathrm{CuCl}+$ $30.466 \mathrm{H}_{2} \mathrm{~S}+4.363 \mathrm{H}_{2} \mathrm{SO}_{4}$

Minor chalcophile elements are all enriched except $\mathrm{Zn}$ and can be incorporated into pyrite and covellite (Table 1); $\mathrm{Sn}$ is added as a trace component to the massive sulfides, possibly as accessory sulfide such as Sn-bearing colusite (Fig. 9e). Minor siderophile elements are either lost like $\mathrm{Ni}$, display near-conservative behavior like $\mathrm{Co}$, or insignificantly enriched (Mo). All trace elements except La are depleted.

Massive sulfide (BB4-48) This high-grade sample with a small amount of residual quartz represents a truly massive sulfide from the high-grade (7\% $\mathrm{Cu}$ average) zone of the $\mathrm{T}$ orebody. All rock-forming elements including silica are brought into solution and removed; addition of large amount of dominantly reduced sulfur is needed to provide for precipitation of pyrite and chalcocite. This sample is characterized by a close coincidence of the isocon line with the constant volume line (Fig. $9 \mathrm{f})$, which in fact suggests a small volume shrinkage (-12\%) that accompanies conversion of the protolith to the massive sulfide. The measured density is lower than the density calculated from mineral proportions, which could be due to the presence of pores and cracks in pyrite that constitute around $5 \%$ of the grain area or the fact that all chalcocite group minerals are considered chalcocite in the calculation with an average density of 5.65, while the actual density of digenite can be lower.

$1000 \mathrm{~g}$ or $407 \mathrm{~cm}^{3}$ of andesite protolith with $\rho=2.46 \mathrm{~g} / \mathrm{cm} 3$

0.249 Trem $+0.951 \mathrm{Ab}+$ $0.558 \mathrm{An}+0.214 \mathrm{Phl}+$ 4.155 Qtz + 0.003 Mt + $0.002 \mathrm{Ccp}+0.59 \mathrm{FeMg}_{-1}+$ $0.588 \mathrm{Al}_{2} \mathrm{Si}_{-1} \mathrm{Mg}_{-1}+$ $6.991 \mathrm{FeCl}_{2}+9.658 \mathrm{CuCl}+$ $18.217 \mathrm{H}_{2} \mathrm{~S}+2.016 \mathrm{H}_{2} \mathrm{SO}_{4}$
1723 g or $342 \mathrm{~cm}^{3}$ massive sulfide, BB4-48 with $\rho=4.89 \mathrm{~g} / \mathrm{cm} 3$

$\rightarrow 0.062 \mathrm{Anh}+0.003 \mathrm{Dia}+$ $0.003 \mathrm{Kln}+0.001 \mathrm{Mus}+$ $7.548 \mathrm{Py}+4.58 \mathrm{Cc}+$ $0.5 \mathrm{Cv}+0.022 \mathrm{Hem}+$ $0.047 \mathrm{Tlc}+9.978 \mathrm{SiO}_{2, \mathrm{aq}}+$ $3.445 \mathrm{Al}(\mathrm{OH})_{3}+0.572 \mathrm{MgCl}_{2}+$ $0.995 \mathrm{CaCl}_{2}+0.951 \mathrm{NaCl}+$ $0.213 \mathrm{KCl}+5.803 \mathrm{H}_{2} \mathrm{O}+$ $19.343 \mathrm{HCl}$ 
Like in the massive sulfide with residual quartz, all minor chalcophile elements are enriched except Zn (Table 2, Fig. 9f). Minor siderophile elements, $\mathrm{Ni}$ and $\mathrm{Co}$, are depleted. Loss of trace elements in the massive sulfide is greater for almost all elements in comparison to any other sample from the $T$ orebody, reflecting complete replacement of the protolith by the massive sulfide ore.

The overall mass transfer and volume change involved in the process that generated the entire massive sulfide orebody can only be discussed subjectively, because we cannot measure the volume fractions of each rock type in three dimensions from the incompletely mapped two-dimensional crosssection of the T orebody and the data from our small samples (Fig. 2b). Breccias are restricted to the margins of the $\mathrm{T}$ orebody and probably constitute a thin outer shell including an even smaller fraction of locally silicified breccia. Likewise, the vuggy residual quartz zone overlying the high-grade core takes up a small fraction of the volume compared with that of the massive sulfides, the red region in Fig. 2b. Despite breccia textures indicating interstitial infilling by hydrothermal minerals, the chemical mass balance of all these rocks (as well as the advanced argillic alteration) indicates minor net volume reduction relative to the protolith andesite (between -1 and $15 \%$ ), which means that alteration led to the creation of net open space. The massive sulfides indicate net volume expansion in the covellite-dominated sample with relict quartz (Fig. 2b), but we infer from the texture of these quartz relics (Fig. 7i) that this extra space creation may have been the result of earlier quartz stockwork veining associated with porphyrystyle alteration. The true massive sulfide sample shows a net volume reduction of $12 \%$ and is more representative for the overall process of massive sulfide replacement, as this ore type is prevalent in the T orebody, as well as in historic samples from Tilva Ros. These observations suggest that the massive sulfide orebody did not form by precipitation into extra space (e.g., opening of large extensional jogs) but rather involved minor volume reduction by chemical dissolution of andesite.

\section{Discussion and conclusion}

This study quantifies the enrichment processes from weakly altered andesite protolith to extremely $\mathrm{Cu}-\mathrm{Au}$ rich massive sulfide ore. Based on the pieces of evidence such as the presence of the relict quartz A or AB-type veins in the central part of the massive sulfide orebody and the absence of anhydrite-sulfide veins inside the massive sulfide, as well as similarity of inclusions in pyrite from epithermal veins and massive sulfide orebody, we conclude that massive sulfide $\mathrm{T}$ orebody presents the final mineralization stage of a single telescoped magmatichydrothermal system at a deep level, superimposed over porphyry mineralization style. Mass balance calculation based on bulk rock analyses, recast into idealized fluid-rock reactions using observed minerals and plausible aqueous reaction partners added and removed by hydrothermal fluid, indicates that the process of formation of almost all mineralization types within the $\mathrm{T}$ orebody can be explained by near-isovolumetric replacement of a common protolith rather than large-scale open-space infilling. Although breccias usually are poor candidates for demonstrating the direct link to the protolith, we observe clasts of the same lithology with different degree of alteration, as well as clasts of veins similar to those observed in the host andesite, and quite consistent behavior of several typically immobile elements, hence confirming that even the breccias can be derived from the same single andesite protolith. The only mineralization type that cannot be confidently explained by isovolumetric replacement is the massive sulfide with residual quartz, where either the assumption of Ti conservation is invalid or open-space infill is more important than replacement, but this may have happened at an earlier stage, most plausibly intense porphyry-style quartz veining. Considering that the most extreme alteration, pure massive sulfide, as well as all milder types of alteration satisfies the parameters consistent with replacement with a small but significant degree of volume loss, the overall process probably included minor net volume loss.

Removal of alkali and alkaline-earth elements in highsulfidation epithermal systems results from the acidity generated by disproportionation of $\mathrm{SO}_{2}$ (Stoffregen 1987; Einaudi et al. 2003), which normally leaves a residual carcass of vuggy quartz. What presents a challenge for the formation of the massive orebodies at Bor is the unusual wholesale removal of quartz during replacive mineralization (Fournier et al. 1982; Akinfiev and Diamond 2009; Monecke et al. 2018). In porphyry stockwork veins, small-scale but widespread quartz dissolution can be facilitated by contraction of a cooling singlephase magmatic fluid leading to synchronous quartz dissolution and sulfide precipitation (Landtwing et al. 2010; Fekete et al. 2016). An alternative possibility for large-scale quartz dissolution could be provided by hot magmatic vapor reaching a seawater or meteoric water horizon, thereby heating up a large amount of non-magmatic water. Removal of silica and re-precipitation of quartz in the silicified advanced argillic breccia at the flanks of the massive sulfide orebody supports the hypothesis of highly reactive, corrosive fluid that could turn the protolith into the massive sulfide. Breccias at the bottom of the $\mathrm{T}$ orebody could represent channelways for the fluid that formed the massive sulfides with rich covellite and chalcocite mineralization. The small but notably negative volume change of the dominant massive sulfide in the $\mathrm{T}$ orebody implies that, after initial brecciation allowing fluid access, the andesite replacement was a selfperpetuating process: the net creation of minor open space would have increased rock permeability, thereby contributing to even stronger focusing of additional fluids into the same 
area. This interpretation is consistent with the fact that the rather sharply defined massive sulfide orebodies are not delineated by major extensional structures.

To further discriminate between the fluid mechanisms leading to the wholesale replacement of an ordinary andesite protolith and its texture-preserving replacement by massive $\mathrm{Fe}$ and $\mathrm{Cu}$ sulfides, we will require evidence from fluid inclusions, especially in opaque minerals. Geochemical changes discussed in this paper can be used as a starting point for future work on modeling the fluid compositions and finding temperature, pressure, chemical, and hydrological conditions that favor the process of formation of high-grade massive sulfide orebodies. Broader geological context, including comparison with the recently discovered neighboring deposit of Cukaru Peki, could further contribute to the understanding of the process that creates massive sulfide orebodies, as a basis for future exploration of these small but extremely valuable orebodies.

Acknowledgments The authors would like to thank Vladica Cvetković, Dimča Jenić, and Blagoje Spaskovski for the organization of the fieldwork at Bor and for the access to the drill core. Valuable field assistance of Djordje Ristovski, Mihailo Mandić, Vladica Racić, Marijana Miletić Filipovski, Milica Manić, and Miloš Velojić and geology discussions with Irena Peytcheva are gratefully acknowledged. We express our sincere gratitude to Lydia Zehnder, Peter Ulmer, Marcel Guillong, and Oscar Laurent for their help with XRF and LA-ICP-MS analyses, and to Remy Lüchinger and Andreas Jallas for excellent sample preparation. We thank Richard Herrington, Bernd Lehmann and Richard Sillitoe for their constructive reviews that helped to improve the clarity of the manuscript.

Funding This study was supported by the Swiss National Science Foundation, Project No. 200021_146651 Mineral resources: Physical dynamics driving chemical enrichment of rare metals. Open access funding provided by Swiss Federal Institute of Technology Zurich.

\section{Compliance with ethical standards}

Conflict of interest The authors declare that they have no conflict of interest.

Open Access This article is licensed under a Creative Commons Attribution 4.0 International License, which permits use, sharing, adaptation, distribution and reproduction in any medium or format, as long as you give appropriate credit to the original author(s) and the source, provide a link to the Creative Commons licence, and indicate if changes were made. The images or other third party material in this article are included in the article's Creative Commons licence, unless indicated otherwise in a credit line to the material. If material is not included in the article's Creative Commons licence and your intended use is not permitted by statutory regulation or exceeds the permitted use, you will need to obtain permission directly from the copyright holder. To view a copy of this licence, visit http://creativecommons.org/licenses/by/4.0/.

\section{References}

Akinfiev NN, Diamond LW (2009) A simple predictive model of quartz solubility in water-salt-CO2 systems at temperatures up to $1000^{\circ} \mathrm{C}$ and pressures up to $1000 \mathrm{MPa}$. Geochim Cosmochim Acta 73: $1597-1608$

Antonijević I (2011) The Novo Okno copper deposit of olistostrome origin (Bor, Eastern Serbia). Geol An Balk Poluostrva 72:101-109

Antonijević I, Mijatović P (2014) The copper deposits of Bor, eastern Serbia: geology and origin of the deposits. Geol An Balk Poluostrva 75:59-74

Antula D (1909) Geological explorations in Timok andesite massive. Godisnjak rudarskog odeljenja Ministarstva narodne privrede 2: 67-94 (in Serbian)

Arribas A (1995) Characteristics of high-sulfidation epithermal deposits, and their relation to magmatic fluid. In: Thompson JFH (ed) Mineralogical Association of Canada Short Course, vol 23. pp $419-454$

Arribas A, Cunningham CG, Rytuba JJ, Rye RO, Kelly WC, Podwysocki MH, Tosdal RM (1995a) Geology, geochronology, fluid inclusions, and isotope geochemistry of the Rodalquilar gold alunite deposit, Spain. Econ Geol 90:795-822

Arribas A, Hedenquist JW, Itaya T, Okada T, Concepción RA, Garcia JS (1995b) Contemporaneous formation of adjacent porphyry and epithermal $\mathrm{Cu}-\mathrm{Au}$ deposits over $300 \mathrm{ka}$ in northern Luzon, Philippines. Geology 23:337-340

Baker T (2019) Gold \pm copper endowment and deposit diversity in the Western Tethyan magmatic belt, Southeast Europe: implications for exploration. Econ Geol 114:1237-1250

Banješević M (2010) Upper cretaceous magmatic suites of the Timok magmatic complex. Geol An Balk Poluostrva 71:13-22

Banješević M, Cvetković V, Von Quadt A, Peytcheva I, Cocić S (2006) Geodynamic reconstructions based on the magmatism in the Timok Magmatic Complex (East Serbia) - part of the Carpathian-Balkan Belt. In: 18th Congress of Carpathian-Balkan Geological Association, Belgrade. pp 27-29

Banješević M, Ingram S, Large D (2014) Copper-gold exploration and discovery in the Timok Magmatic Complex, Serbia. In: EGU General Assembly Vienna. Geophysical Research Abstracts, pp $16450-16451$

Baumgartner R, Fontboté L, Vennemann T (2008) Mineral zoning and geochemistry of epithermal polymetallic $\mathrm{Zn}-\mathrm{Pb}-\mathrm{Ag}-\mathrm{Cu}-\mathrm{Bi}$ mineralization at Cerro de Pasco, Peru. Econ Geol 103:493-537

Berger BR, Henley RW (1989) Advances in the understanding of epithermal gold-silver deposits, with special reference to the western United States. In: Keays RR, Ramsay WRH, Groves DI (eds) The geology of gold deposits: the perspective in 1988. Soc Econ Geol Monogr, vol 6. pp. 405-423

Berza T, Constantinescu E, Vlad SN (1998) Upper cretaceous magmatic series and associated mineralisation in the Carpathian-Balkan Orogen. Resour Geol 48:291-306

Bogdanov B (1984) Hydrothermal systems of massive sulphide, porphyry-copper and vein copper deposits of Sredna Gora zone in Bulgaria. In: VI Symposium IAGOD, Stuttgart, Germany, 1984. pp. 63-67

Brouwer P (2006) Theory of XRF: getting acquainted with the principles. PANalytical BV, Almelo

Chambefort I (2005) The $\mathrm{Cu}-\mathrm{Au}$ Chelopech Deposit, Panagyurishte District, Bulgaria: volcanic setting, hydrothermal evolution and tectonic overprint of a Late Cretaceous high-sulfidation epithermal deposit. $\mathrm{PhD}$ thesis, Université de Genève

Chambefort I, Moritz R (2014) Subaqueous environment and volcanic evolution of the Late Cretaceous Chelopech $\mathrm{Au}-\mathrm{Cu}$ epithermal deposit, Bulgaria. J Volcanol Geotherm Res 289:1-13

Chen J, Cooke DR, Piquer J, Selley D, Zhang L, White NC (2019) Hydrothermal alteration, mineralization, and structural geology of the Zijinshan high-sulfidation $\mathrm{Au}-\mathrm{Cu}$ deposit, Fujian province, Southeast China. Econ Geol 114:639-666

Crane D, Kavalieris I, Hedenquist JW, Harris M, Camus F (2012) Geologic overview of the Oyu Tolgoi porphyry $\mathrm{Cu}-\mathrm{Au}-\mathrm{Mo}$ 
deposits, Mongolia. In: Hedenquist JW, Harris M, Camus F (eds) Geology and genesis of major copper deposits and districts of the world: a tribute to Richard H. Sillitoe. Soc Econ Geol Spec Publ, vol 16. pp. 187-213

Đorđević M (2005) Volcanogenic Turonian and epiclastics of senonian in the Timok magmatic complex between Bor and the Tupižnica mountain, eastern Serbia. Geol An Balk Poluostrva 66:63-71

Đorđević M, Banješević M (1997) The geology of the southern part of Timok eruptive area, the interpreter booklet and geological map 1: 50000. Savezno Ministarstvo za privredu, Beograd

Drovenik M (1953) On the origin of ore minerals in the Bor copper mine. In: Geologija, razprave in poročila, vol 1. Ljubljana, pp 225-242

Drovenik M, Leskovšek H, Pezdić J (1975) Isotopic composition of sulfur in the ore deposits of the Timok volcanic district. Rudarskometalurški zbornik 21:319-362 (in Slovenian)

Drummond SE, Ohmoto H (1985) Chemical evolution and mineral deposition in boiling hydrothermal systems. Econ Geol 80:126-147

Einaudi MT, Hedenquist JW, Inan EE (2003) Sulfidation state of hydrothermal fluids: the porphyry-epithermal transition and beyond. In: Simmons SF, Graham I (eds) Volcanic, geothermal, and oreforming fluids: rulers and witnesses of processes within the earth. Soc Econ Geol Spec Publ, vol 10. pp. 285-313

Fekete S, Weis P, Driesner T, Bouvier A-S, Baumgartner L, Heinrich CA (2016) Contrasting hydrological processes of meteoric water incursion during magmatic-hydrothermal ore deposition: an oxygen isotope study by ion microprobe. Earth Planet Sci Lett 451:263-271

Fournier RO, Rosenbauer RJ, Bischoff JL (1982) The solubility of quartz in aqueous sodium chloride solution at $350{ }^{\circ} \mathrm{C}$ and 180 to 500 bars. Geochim Cosmochim Acta 46:1975-1978

Gallhofer D, Quadt AV, Peytcheva I, Schmid SM, Heinrich CA (2015) Tectonic, magmatic, and metallogenic evolution of the late cretaceous arc in the Carpathian-Balkan Orogen. Tectonics 34:18131836

Giggenbach WF (1992) SEG distinguished lecture: magma degassing and mineral deposition in hydrothermal systems along convergent plate boundaries. Econ Geol 87:1927-1944

Grant JA (2005) Isocon analysis: a brief review of the method and applications. Phys Chem Earth, Parts A/B/C 30:997-1004

Gresens RL (1967) Composition-volume relationships of metasomatism. Chem Geol 2:47-65

Grubić A (1974) Eastern Serbia in the light of the new global tectonics: consequences of this model for the interpretation of the tectonics of the northern branch of the Alpides. In: Janković S (ed) Metallogeny and Concepts of the Geotectonic Development of Yugoslavia. Belgrade, pp 179-211

Gruen G, Weis P, Driesner T, Heinrich CA, de Ronde CEJ (2014) Hydrodynamic modeling of magmatic-hydrothermal activity at submarine arc volcanoes, with implications for ore formation. Earth Planet Sci Lett 404:307-318

Guillong M, Meier DL, Allan MM, Heinrich CA, Yardley BW (2008) Appendix A6: SILLS: a MATLAB-based program for the reduction of laser ablation ICP-MS data of homogeneous materials and inclusions. In: Sylvester P (ed) Laser ablation ICP-MS in the earth sciences: current practices and outstanding issues. Mineralogical Association of Canada Short Course Series, vol 40. pp. 328-333

Günther D, Quadt AV, Wirz R, Cousin H, Dietrich VJ (2001) Elemental analyses using laser ablation-inductively coupled plasma-mass spectrometry (LA-ICP-MS) of geological samples fused with Li2B4O7 and calibrated without matrix-matched standards. Microchim Acta 136:101-107

Halley S (2020) Mapping magmatic and hydrothermal processes from routine exploration geochemical analyses. Econ Geol 115:489-503

Heald P, Foley NK, Hayba DO (1987) Comparative anatomy of volcanichosted epithermal deposits; acid-sulfate and adularia-sericite types. Econ Geol 82:1-26
Hedenquist JW, Lowenstern JB (1994) The role of magmas in the formation of hydrothermal ore deposits. Nature 370:519-527

Hedenquist JW, Aoki M, Shinohara H (1994) Flux of volatiles and oreforming metals from the magmatic-hydrothermal system of Satsuma Iwojima volcano. Geology 22:585-588

Hedenquist JW, Arribas A, Reynolds TJ (1998) Evolution of an intrusion-centered hydrothermal system; Far Southeast-Lepanto porphyry and epithermal $\mathrm{Cu}-\mathrm{Au}$ deposits, Philippines. Econ Geol 93:373-404

Heinrich CA (2005) The physical and chemical evolution of low-salinity magmatic fluids at the porphyry to epithermal transition: a thermodynamic study. Mineral Deposita 39:864-889

Heinrich CA, Bain JHC, Mernagh TP, Wyborn LAI, Andrew AS, Waring CL (1995) Fluid and mass transfer during metabasalt alteration and copper mineralization at Mount Isa, Australia. Econ Geol 90:705730

Heinrich CA, Driesner T, Stefánsson A, Seward TM (2004) Magmatic vapor contraction and the transport of gold from the porphyry environment to epithermal ore deposits. Geology 32:761-764

Hemley JJ, Hunt JP (1992) Hydrothermal ore-forming processes in the light of studies in rock-buffered systems; II, some general geologic applications. Econ Geol 87:23-43

Henley RW, McNabb A (1978) Magmatic vapor plumes and groundwater interaction in porphyry copper emplacement. Econ Geol 73: $1-20$

Humphris SE, Alt JC, Teagle DA, Honnorez JJ (1998) Geochemical changes during hydrothermal alteration of basement in the stockwork beneath the active TAG hydrothermal mound. In: Proceedings of the Ocean Drilling Program, Scientific Results, vol 158. National Science Foundation, pp 255-276

Jakubec J, Pittuck M, Samoukovic M et al. (2018) NI43-101 technical report - pre-feasibility study for the Timok Project, Serbia. https:/ www.sec.gov/Archives/edgar/data/919991/000147237518000056/ exhibit99-1.htm. Accessed 25 Sept 2020

Jamasmie C (2018) China's Zijin wins race for Serbia's largest copper mine. https://www.mining.com/chinas-zijin-wins-race-serbiaslargest-copper-mine. Accessed 31 Jan 2020

Janković S (1977) The copper deposits and geotectonic setting of the Tethyan Eurasian Metallogenic Belt. Mineral Deposita 12:37-47

Janković S (1990) The ore deposits of Serbia: regional metallogenic settings, environments of deposition, and types. Faculty of Mining and Geology, Belgrade (in Serbian with English summary)

Janković S (1997) The Carpatho-Balkanides and adjacent area: a sector of the Tethyan Eurasian metallogenic belt. Mineral Deposita 32:426433

Janković S, Terzić M, Aleksić D et al. (1980) Metallogenic features of copper deposits in the volcano-intrusive complexes of the Bor District, Yugoslavia. In: Janković S, Sillitoe RH (eds) European Copper Deposits. SGA Spec. Publ, vol 1. pp. 42-49

Janković S, Jelenković R, Koželj D (2002) The Bor copper and gold deposit. QWERTY, Bor

Jelenković R, Milovanović D, Koželj D, Banješević M (2016) The mineral resources of the Bor Metallogenic zone: a review. Geologia Croatica 69:143-155

Karamata S, Knežević V, Pecskay Z, Đorđević M (1997) Magmatism and metallogeny of the Ridanj-Krepoljin belt (eastern Serbia) and their correlation with northern and eastern analogues. Mineral Deposita 32:452-458

Khokhlova I, Kuz'mina T, Roshchina I (2014) Multielement determination of the composition of sulfide ores using X-ray fluorescence analysis. J Anal Chem 69:705-714

Knaak M, Márton I, Tosdal RM et al. (2016) Geologic setting and tectonic evolution of porphyry $\mathrm{Cu}-\mathrm{Au}$, polymetallic replacement, and sedimentary rock-hosted $\mathrm{Au}$ deposits in the northwest area of the Timok magmatic complex, Serbia. In: Richards JP (ed) Tectonics 
and Metallogeny of the Tethyan Orogenic Belt. Soc Econ Geol Spec Publ, vol 19. pp. 1-28

Kolb M (2011) Geochronology and isotope geochemistry of magmatic rocks from Western Srednogorie (Bulgaria) and Timok Magmatic Complex (East Serbia). PhD thesis, ETH Zurich

Kolb M, Von Quadt A, Peytcheva I, Heinrich CA, Fowler SJ, Cvetkovic V (2012) Adakite-like and normal arc magmas: distinct fractionation paths in the east Serbian segment of the Balkan-Carpathian arc. J Petrol 54:421-451

Kouzmanov K, Moritz R, von Quadt A, Chiaradia M, Peytcheva I, Fontignie D, Ramboz C, Bogdanov K (2009) Late cretaceous porphyry $\mathrm{Cu}$ and epithermal $\mathrm{Cu}-\mathrm{Au}$ association in the southern Panagyurishte District, Bulgaria: the paired Vlaykov Vruh and Elshitsa deposits. Mineral Deposita 44:611-646

Koželj D (2002) Epithermal gold mineralization in the Bor metallogenic zone: morphogenetic types, structural-texture varieties and potentiality. Grafomed, Bor

Koželj D, Canby V, Naftali L (2016) Timok Cu-Au district, Serbia: A review of recent exploration and discovery. https://www.segweb. org/SEG/ Events/Conference Archive/2016/Conference Proceedings/files/pdf/Oral-Presentations/Abstracts/Kozelj.pdf. Accessed 25 Sept 2020

Landtwing MR, Furrer C, Redmond PB, Pettke T, Guillong M, Heinrich CA (2010) The Bingham canyon porphyry Cu-Mo-Au deposit. III. Zoned copper-gold ore deposition by magmatic vapor expansion. Econ Geol 105:91-118

Lasdon LS, Waren AD, Jain A, Ratner M (1978) Design and testing of a generalized reduced gradient code for nonlinear programming. ACM Trans Math Softw 4:34-50

Lazarević M (1909) Neue Beobachtungen über die Enargit-Covellin Lagerstätten von Bor und verwandte Vorkommen. Z Prakt Geol XVII:177-179

Lerouge C, Bailly L, Béchu E et al. (2005) Age and origin of advanced argillic alteration at the Bor $\mathrm{Cu}-\mathrm{Au}$ deposit, Serbia. In: Mao J, Bierlein FP (eds) Mineral Deposit Research: Meeting the Global Challenge. Proceedings of the Eighth Biennial SGA Meeting China, Springer Berlin Heidelberg, pp 41-44

Ling MX, Liu Y, Zhang H, Sun W (2014) Sample preparation and X-ray fluorescence analysis of sulfide ores. Anal Lett 47:1598-1605

Lips AL, Herrington RJ, Stein G, Kozelj D, Popov K, Wijbrans JR (2004) Refined timing of porphyry copper formation in the Serbian and Bulgarian portions of the Cretaceous Carpatho-Balkan Belt. Econ Geol 99:601-609

Ljubović-Obradović D, Carević I, Mirković M, Protić N (2011) Upper Cretaceous volcanoclastic-sedimentary formations in the Timok eruptive area (eastern Serbia): new biostratigraphic data from planktonic foraminifera. Geol Carpath 62:435-446

Longo AA, Dilles JH, Grunder AL, Duncan R (2010) Evolution of calcalkaline volcanism and associated hydrothermal gold deposits at Yanacocha, Peru. Econ Geol 105:1191-1241

Losada-Calderón AJ, McPhail DC (1996) Porphyry and high-sulfidation epithermal mineralization in the Nevados del Famatina mining district, Argentina. In: Corbett GJ, Leach TM (eds) Andean copper deposits: new discoveries, mineralization, styles and metallogeny. Soc Econ Geol Spec Publ, vol 5. pp. 91-118

Mancano DP, Campbell AR (1995) Microthermometry of enargitehosted fluid inclusions from the Lepanto, Philippines, highsulfidation $\mathrm{Cu} \mathrm{Au}$ deposit. Geochim Cosmochim Acta 59:39093916

Matenco L, Radivojević D (2012) On the formation and evolution of the Pannonian Basin: constraints derived from the structure of the junction area between the Carpathians and Dinarides. Tectonics 31: TC6007

Mavrogenes J, Henley RW, Reyes AG, Berger B (2010) Sulfosalt melts: evidence of high-temperature vapor transport of metals in the formation of high-sulfidation lode gold deposits. Econ Geol 105: $257-262$

Mempel G (1937) Die Kupfererzlägerstatte von Bor in Jugoslavien. Metall und Erz 34:551-555

Meyer C, Shea E, Goddard C (1968) Ore deposits at Butte, Montana. In: ridge JD (ed) Ore deposits of the United States 1933-1967, vol 2. American Institute of Mining, metallurgical, and petroleum engineers, New York, pp 1363-1416

Mioč P (1983) Osnovna geološka karta SFR Jugoslavije 1:100000. Zvezni geološki zavod, Beograd

Monecke T, Monecke J, Reynolds TJ, Tsuruoka S, Bennett MM, Skewes WB, Palin RM (2018) Quartz solubility in the $\mathrm{H} 2 \mathrm{O}-\mathrm{NaCl}$ system: a framework for understanding vein formation in porphyry copper deposits. Econ Geol 113:1007-1046

Ohmoto H, Goldhaber M (1997) Sulphur and carbon isotopes. In: Barnes HL (ed) Geochemistry of hydrothermal ore deposits. 3rd edn. Wiley, New York, pp 517-612

Pan JY, Ni P, Chi Z, Wang WB, Zeng WC, Xue K (2019) Alunite 40Ar/ 39Ar and zircon U-Pb constraints on the magmatic-hydrothermal history of the Zijinshan high-sulfidation epithermal $\mathrm{Cu}-\mathrm{Au}$ deposit and the adjacent Luoboling porphyry $\mathrm{Cu}-\mathrm{Mo}$ deposit, South China: implications for their genetic association. Econ Geol 114:667-695

Pittuck M, McGurk T (2016) NI43-101 Preliminary economic assessment of the Cukaru Peki Upper Zone deposit, Serbia. https://www. sec.gov/Archives/edgar/data/919991/000147237518000033/ exhibit99-1.htm. Accessed 25 Sept 2020

Popov K (2001) Porphyry copper-massive sulphide system in the Radka ore district (Bulgaria). In: Annual of the University of Mining and Geology, vol 43-44. pp. 65-71

Pudack C, Halter WE, Heinrich CA, Pettke T (2009) Evolution of magmatic vapor to gold-rich epithermal liquid: the porphyry to epithermal transition at Nevados de Famatina, Northwest Argentina. Econ Geol 104:449-477

Rainbow A (2009) Genesis and evolution of the Pierina high-sulphidation epithermal Au-Ag Deposit, Ancash, Perú. PhD thesis, Queen's University, Kingston, Ontario

Reed M, Rusk BG, Palandri J (2013) The Butte magmatic-hydrothermal system: one fluid yields all alteration and veins. Econ Geol 108: 1379-1396

Rottier B, Kouzmanov K, Bouvier A-S, Baumgartner LP, Wälle M, Rezeau H, Bendezú R, Fontboté L (2016) Heterogeneous melt and hypersaline liquid inclusions in shallow porphyry type mineralization as markers of the magmatic-hydrothermal transition (Cerro de Pasco district, Peru). Chem Geol 447:93-116

Rusk BG, Reed MH, Dilles JH (2008) Fluid inclusion evidence for magmatic-hydrothermal fluid evolution in the porphyry coppermolybdenum deposit at Butte, Montana. Econ Geol 103:307-334

Schmid SM, Bernoulli D, Fügenschuh B, Matenco L, Schefer S, Schuster R, Tischler M, Ustaszewski K (2008) The Alpine-CarpathianDinaridic orogenic system: correlation and evolution of tectonic units. Swiss J Geosci 101:139-183

Schumacher F (1954) The ore deposits of Jugoslavia and the development of its mining industry. Econ Geol 49:451-492

Sillitoe RH (1980) The Carpathian-Balkan porphyry copper belt - a Cordilleran perspective. In: Janković S, Sillitoe RH (eds) European Copper Deposits SGA Spec Publ vol 1. pp. 26-35

Sillitoe RH (1983) Enargite-bearing massive sulfide deposits high in porphyry copper systems. Econ Geol 78:348-352

Sillitoe RH (2010) Porphyry copper systems. Econ Geol 105:3-41

Sillitoe RH, Burgoa C, Hopper D (2016) Porphyry copper discovery beneath the Valeriano lithocap, Chile. Soc Econ Geol Newsletter 106:1-20

Starostin VI (1970) Bor and Maidanpek copper deposits in Yugoslavia. Int Geol Rev 12:370-380

Stoffregen RE (1987) Genesis of acid-sulfate alteration and $\mathrm{Au}-\mathrm{Cu}-\mathrm{Ag}$ mineralization at Summitville, Colorado. Econ Geol 82:1575-1591 
Thompson JB (1982) Composition space: an algebraic and geometric approach. In: Ferry JM (ed) Characterization of metamorphism through mineral equilibria. MSA reviews in mineralogy, vol 10. pp. $1-31$

Tončić T (2018) Balance of copper reserves of the Bor mine: unpublished reserve statement of RTB Bor

Ulrich T, Heinrich C (2002) Geology and alteration geochemistry of the porphyry $\mathrm{Cu}-\mathrm{Au}$ deposit at Bajo de la Alumbrera, Argentina. Econ Geol 97:1865-1888

Von Quadt A, Peytcheva I, Cvetkovic V, Banjesevic M, Kozelj D (2002) Geochronology, geochemistry and isotope tracing of the Cretaceous magmatism of East Serbia as part of the Apuseni-TimokSrednogorie metallogenic belt. Geol Carpath 53:175-177

Von Quadt A, Moritz R, Peytcheva I, Heinrich CA (2005) 3: geochronology and geodynamics of Late Cretaceous magmatism and $\mathrm{Cu}-$ Au mineralization in the Panagyurishte region of the ApuseniBanat-Timok-Srednogorie belt, Bulgaria. Ore Geol Rev 27:95-126

Von Quadt A, Peytcheva I, Heinrich C, Cvetković V, Banjesević M, Andrew CJ (2007) Upper Cretaceous magmatic evolution and related $\mathrm{Cu}-\mathrm{Au}$ mineralization in Bulgaria and Serbia. In: Proceedings of the Ninth Biennial Meeting of the Society for Geology Applied to
Mineral Deposits SGA, Dublin. Irish Association for Economic Geology, pp 861-864

Vuchkova L, Jordanov J (2000) Fusion method for preparation of refractory nickel based alloy powders for X-ray fluorescence spectrometry. Analyst 125:1681-1685

Wang Y, Sasaki M, Sasada M, Chen CH (1999) Fluid inclusion studies of the Chinkuashih high-sulfidation gold-copper deposits in Taiwan. Chem Geol 154:155-167

Weed WH (1912) Geology and ore deposits of the Butte district, Montana. USGS Professional Paper 74. US Government Printing Office, Washington

Willis J (2010) Glass beads by borate fusion. PANalytical B.V. https:// www.malvernpanalytical.com/en/assets/Glass-beads-by-boratefusion_tcm50-54735.pdf. Accessed 25 Sept 2020

Zimmerman A, Stein HJ, Hannah JL, Koželj D, Bogdanov K, Berza T (2008) Tectonic configuration of the Apuseni-Banat-TimokSrednogorie belt, Balkans-South Carpathians, constrained by high precision Re-Os molybdenite ages. Mineral Deposita 43:1-21

Publisher's note Springer Nature remains neutral with regard to jurisdictional claims in published maps and institutional affiliations. 